\title{
Genera of orders Actiniaria and Corallimorpharia (Cnidaria, Anthozoa, Hexacorallia), and their type species*
}

\author{
DAPHNE GAIL FAUTIN, TARAS ZELENCHUK \& DINESH RAVEENDRAN \\ Department of Ecology and Evolutionary Biology, and Natural History Museum, University of Kansas, Lawrence, Kansas 66045 USA \\ fautin@ku.edu
}

*In: Zhang, Z.-Q. \& Shear, W.A. (Eds) (2007) Linnaeus Tercentenary: Progress in Invertebrate Taxonomy. Zootaxa, $1668,1-766$.

\section{Table of contents}

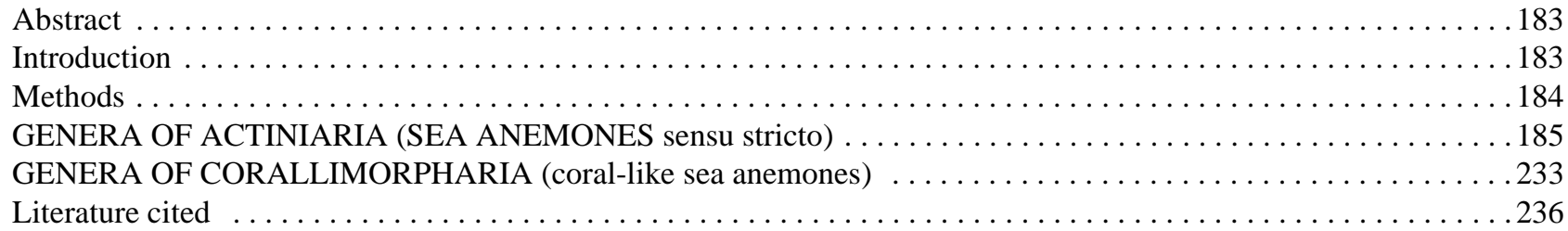

\begin{abstract}
We determined the type species, if any, for the 425 genera of the order Actiniaria and for the 19 genera of order Corallimorpharia. In Actiniaria, 393 genera have a clear type species; 46 generic names are homonyms, 17 of which are senior, 26 of which are junior (six have been replaced), and three are both junior and senior. Of the 18 available genera of Corallimorpharia, there are no junior homonyms, and one senior homonym.
\end{abstract}

Key words: sea anemones, nomenclature, taxonomy

\section{Introduction}

Cnidarian order Actiniaria (sea anemones sensu stricto) is a relatively small taxon, containing 1426 nominal species, of which 1103 are currently considered valid (Fautin 2007). However, it is rich in genera, 425 having been made available. We determined the type species, if any, for all genera of the order Actiniaria, as well as for the 19 genera of order Corallimorpharia (members of which resemble sea anemones in lack of a skeleton, but are like scleractinian corals in morphology and nematocysts: e.g. Fautin et al. 2002). For any homonyms of generic names, we determined seniority. We consulted the publication in which the genus was described to ascertain whether it had been typified in accordance with the International Code of Zoological Nomenclature (ICZN) (International Commission of Zoological Nomenclature 1999). Our nomenclatural findings are also available through the on-line database "Hexacorallians of the World" (Fautin 2007).

We found 392 of the 425 genera of Actiniaria to have a clear type species; we designated that of one additional genus. Forty-six of the generic names are homonyms, five of them within Actiniaria (the names Buno- 
della, Cladactis, Paraphellia, Phelliopsis, and Stephanactis each was used for two genera of sea anemones). In 17 cases, the sea anemone name is senior; of the 26 junior homonyms, seven have been replaced; three names are both junior and senior homonyms. Of the 18 available generic names of Corallimorpharia, there are no junior homonyms and one senior homonym; 13 are currently considered valid.

The name Endocoelactis was proposed for an actiniarian genus by Carlgren (1897) but no species was attributed to the genus, so it is a nomen nudum (ICZN Article 12.2.5). The name Chalmersia was proposed for a corallimorpharian by Delage and Hérouard (1901) but no species was attributed to it, so it is a nomen nudum (ICZN Art. 12.2.5).

\section{Methods}

We follow the current classification of higher taxa. Thus, although some corallimorpharians were described as actiniarians, we treat them as corallimorpharians. Reciprocally, some species of sea anemones have been placed in corallimorpharian genera Discosoma, Discosomoides, and Rhodactis. This accounts for those names appearing in the pick list of actiniarian genera in the on-line resource "Hexacorallians of the World" (Fautin 2007), although we do not include those genera among Actiniaria below. The name Paradiscosoma could be mistaken for that of a corallimorpharian, but its type genus is a zoanthid; likewise, the zoanthid genus Isaura has been used for a corallimorpharian; the type species of the genus Cereus is a cerianthid: none of these are included here. We include in Actiniaria genera that previously constituted hexacorallian order Ptychodactiaria: Cappola and Fautin (2000) demonstrated there is no basis for separating Ptychodactiaria from Actiniaria. Generic names such as Hydra, Lucernaria, Medusa, and Urtica have been applied to sea anemones but properly belong to non-anthozoan cnidarians. The non-cnidarian name Holothuria has been applied to sea anemones; one sea anemone genus was described as an echinoderm, one as a sipunculid, and one as a mollusc. We did not include in this inventory the name Priapus, which was first coined for a sea anemone (Linnaeus 1758), but was suppressed for that taxon in Opinion 1295 of the International Commission on Zoological Nomenclature (1985).

Information from the published literature (primarily taxonomic but also biogeographic, ecological, toxicological, etc.) has been assembled in "Hexacorallians of the World" (Fautin 2007). We consulted the original description of every actiniarian and corallimorpharian genus to ensure accuracy of the information. We also referred to reversionary works and catalogs of sea anemones and corallimorpharians (e.g. Andres 1883; Carlgren 1949), Nomenclator Zoologicus (NZ) (Neave 1939a, b, 1940a, b, 1950; Edwards \& Hopwood 1966; Edwards \& Vevers 1975; Edwards \& Tobias 1993; Edwards et al. 1996; and additions that nominally constitute volume 10, available, along with information from all print volumes, at http://uio.mbl.edu/NomenclatorZoologicus), and opinions of the International Commission of Zoological Nomenclature, including those on the Official Lists and Indexes of Names and Works in Zoology (International Commission on Zoological Nomenclature 1987). Our decisions were based on Chapter 15 of the ICZN that deals with "Types in the genus group."

The entry for each genus provides the author and date of its publication, and author, date, and criterion for fixation of its type species. Carlgren (1949) specified a type species (which he termed a genotype) for genera in which he included more than one species, but did not for genera containing only a single species; we do not consider that he thereby indicated that one species to be the type species. For type species of replacement names, we follow ICZN Article 67.8 ("both the prior nominal taxon and its replacement have the same type species"), although that rule was not previously observed for some of them. Nomenclature notes include comparison for authorship of the genus with what is provided in NZ and Carlgren (1949). We note species that are the type of more than one genus, but not for replacement names. Spelling variants, if any, found in the literature we surveyed include misspellings as well as alternatives that may have been original but are not 
allowed by the current ICZN, such as words that contain hyphens or diacritic marks. The final line of each entry concerning validity is based on the published literature: if that genus contains any species that have not been transferred to other species or synonymized with species in other genera, it is listed as valid. Species that have not been formally transferred when a genus is synonymized or the genus name is replaced will show up under the original name; thus the number of valid genera appears higher than it really is.

We also consulted the original descriptions of taxa bearing homonymous names to ascertain spellings and dates. References for homonyms are given only within the text - and only the page on which the name appears is cited, as in NZ. Our determinations are according to the "Principle of Priority" (ICZN Article 23.1).

\section{GENERA OF ACTINIARIA (SEA ANEMONES sensu stricto)}

Aceractis Andres, 1883

Type species: Actinia primula Drayton in Dana, 1846, by monotypy.

Nomenclature notes: Not listed in NZ (Neave 1939a, b, 1940a, b, 1950; Edwards \& Hopwood 1966; Edwards \& Vevers 1975; Edwards \& Tobias 1993; Edwards et al. 1996; volume 10 on line).

Currently considered valid: No

Acerominyas Andres, 1883

Type species: Actinia viridula Quoy and Gaimard, 1833, by monotypy.

Nomenclature notes: Authorship is in agreement with Neave (1939a).

Currently considered valid: No

Acontiactis England, 1990

Type species: Acontiactis gokhaleae England, 1990, by original designation.

Nomenclature notes: Authorship is in agreement with Edwards et al. (1996).

Currently considered valid: Yes

Acontiophorum Carlgren, 1938

Type species: Acontiophorum mortenseni Carlgren, 1938, by monotypy.

Nomenclature notes: Authorship is in agreement with Neave (1950).

Currently considered valid: Yes

Acraspedanthus Carlgren, 1924a

Type species: Acraspedanthus elongatus Carlgren, 1924a, by monotypy.

Nomenclature notes: Authorship is in agreement with Neave (1939a) and with Carlgren (1949).

Currently considered valid: Yes

Acremodactyla Kwietniewski, 1897

Type species: Acremodactyla ambonensis Kwietniewski, 1897, by monotypy.

Nomenclature notes: Authorship is in agreement with Neave (1939a).

Currently considered valid: No

Acthelmis Lütken, 1875

Type species: Actinia intestinalis Fabricius, 1780, by monotypy.

Nomenclature notes: Authorship is in agreement with Neave (1939a) and with Carlgren (1949).

Currently considered valid: Yes 
Actinauge Verrill, 1883

Type species: Actinia nodosa Fabricius, 1780, by original designation.

Nomenclature notes: Type species is not in agreement with Carlgren (1949). Authorship is in agreement with Neave (1939a, 1940b) and with Carlgren (1949).

Currently considered valid: Yes

Actinecta de Blainville, 1830

Type species: Mynias cyanea Cuvier, 1817, by replacement.Nomenclature notes: Replacement name (ICZN Article 60.2) for the junior homonym Minyas. Authorship is in agreement with Neave (1939a).

Currently considered valid: No

Actineria de Blainville, 1830

Type species: Actineria villosa Quoy et Gaimard in de Blainville, 1830, by monotypy.

Nomenclature notes: Carlgren (1949) erroneously gave 1833 as the date of the type species. Authorship is in agreement with Neave (1939a) and with Carlgren (1949).

Currently considered valid: Yes

Actinernus Verrill, 1879

Type species: Actinernus nobilis Verrill, 1879, by monotypy.

Nomenclature notes: Type species is in agreement with Carlgren (1949). Authorship is in agreement with Neave (1939a) and with Carlgren (1949).

Spelling errors or variants: Actinonernus

Currently considered valid: Yes

Actinia Linnaeus, 1767

Type species: Priapus equinus Linnaeus, 1758, by subsequent designation.

Nomenclature notes: Type species was designated by Thompson (1858), and is in agreement with Carlgren (1949) and Opinion 1295 of the International Commission on Zoological Nomenclature (Bulletin of Zoological Nomenclature 42:34-36; April 1985). Authorship is in agreement with Neave (1939a) but not with Carlgren (1949).

Spelling errors or variants: Actinea, Actínia

Currently considered valid: Yes

Actiniogeton Carlgren, 1938

Type species: Actinoides sultana Carlgren, 1900a, by monotypy.

Nomenclature notes: Type species and authorship are in agreement with Carlgren (1949); not listed in NZ (Neave 1939a, b, 1940a, b, 1950; Edwards \& Hopwood 1966; Edwards \& Vevers 1975; Edwards \& Tobias 1993; Edwards et al. 1996; volume 10 on line).

Currently considered valid: No

Actinioides Haddon and Shackleton, 1893

Type species: Actinioides Dixoniana Haddon and Shackleton, 1893, by subsequent designation.

Nomenclature notes: Type species was designated by Carlgren (1945). Authorship is in agreement with Neave (1939a).

Spelling errors or variants: Actiniodes, Actinoides

Currently considered valid: No

Actinocereus de Blainville, 1830

Type species: Hydra disciflora Gaertner, 1762, by original designation.

Nomenclature notes: No type species has been designated for this genus; seven species were included in it originally.

Authorship is in agreement with Neave (1939a).

Currently considered valid: No

Actinodactylus Duchassaing, 1850

Type species: Actinodactylus Boscii Duchassaing, 1850, by monotypy.

Nomenclature notes: In agreement with Neave (1939a), senior homonym of temnocephalan genus Actinodactylus of 
Haswell, W. A., 1893, Jottings from the biological laboratory of Sydney University. Proceedings of the Linnean Society of New South Wales, series 2, 7:342. Actinodactylus Boscii is also type species of Stauractis. Authorship of both genera is in agreement with Neave (1939a).

Currently considered valid: Yes

Actinodendron de Blainville, 1830

Type species: Actinodendron arborea Quoy et Gaimard in de Blainville, 1830, by subsequent designation.

Nomenclature notes: Type species was designated by Carlgren (1949), but the date was given as 1833. Authorship is in agreement with Neave (1939a) but Carlgren (1949) erroneously gave 1930 as the date.

Spelling errors or variants: Actinodendrum

Currently considered valid: Yes

Actinoloba de Blainville, 1830

Type species: None

Nomenclature notes: No type species has been designated for this genus; four species were included in it originally. Authorship is in agreement with Neave (1939a).

Currently considered valid: No

Actinolobopsis Verrill, 1899b

Type species: Actinia reticulata Couthouy in Dana, 1846, by original designation.

Nomenclature notes: Authorship is in agreement with Neave (1939a). Created by Verrill (1899b) as a replacement name for Actinoloba which he attributed to Hertwig (1882). However, Hertwig did not propose this name; presumably, Verrill confused it with Hertwig's Antholoba. Therefore, it was an unnecessary replacement name, but is available (ICZN Article 10.6).

Currently considered valid: No

Actinoporus Duchassaing, 1850

Type species: Actinoporus elegans Duchassaing, 1850, by monotypy.

Nomenclature notes: Type species is in agreement with Carlgren (1949). Authorship is in agreement with Neave (1939a) and with Carlgren (1949).

Currently considered valid: Yes

Actinopsis Danielssen and Koren, 1856

Type species: Actinopsis flava Danielssen and Koren, 1856, by monotypy.

Nomenclature notes: In agreement with Neave (1939a), senior homonym of echinoderm genus Actinopsis of Lambert, J., 1897, Note sur quelques échinides éocènes de l'Aude. Bulletin de la Société Géologique de France, series 3, $25: 507$. Neave (1939a) erroneously attributed authorship of the actiniarian genus to Koren and Danielssen, and of the echinoderm genus to Lambert in 1898 (in a publication different from the one cited here).

Currently considered valid: Yes

Actinoscyphia Stephenson, 1920

Type species: Actinernus saginatus Verrill, 1882, by original designation.

Nomenclature notes: Type species is in agreement with Carlgren (1949). Authorship is in agreement with Neave (1939a) and with Carlgren (1949).

Currently considered valid: Yes

Actinoscyphiopsis Carlgren, 1928a

Type species: Actinernus aurelia Stephenson, 1918b, by monotypy.

Nomenclature notes: Not listed in NZ (Neave 1939a, b, 1940a, b, 1950; Edwards \& Hopwood 1966; Edwards \& Vevers 1975; Edwards \& Tobias 1993; Edwards et al. 1996; volume 10 on line).

Currently considered valid: No

Actinostella Duchassaing, 1850

Type species: Actinostella formosa Duchassaing, 1850, by monotypy. 
Nomenclature notes: Authorship is in agreement with Neave (1939a).

Currently considered valid: Yes

Actinostephanus Kwietniewski, 1897

Type species: Actinostephanus Haeckeli Kwietniewski, 1897, by monotypy.

Nomenclature notes: Authorship is in agreement with Neave (1939a) and with Carlgren (1949).

Currently considered valid: Yes

Actinostola Verrill, 1883

Type species: Urticina callosa Verrill, 1882, by original designation.

Nomenclature notes: Type species is in agreement with Carlgren (1949). Authorship is in agreement with Neave (1939a) and with Carlgren (1949).

Currently considered valid: Yes

Actinothoe Fischer, 1889

Type species: Sagartia sphyrodeta Gosse, 1858 b, by monotypy.

Nomenclature notes: Type species is in agreement with Carlgren (1949). Authorship is in agreement with Carlgren (1949); not listed in NZ (Neave 1939a, b, 1940a, b, 1950; Edwards \& Hopwood 1966; Edwards \& Vevers 1975; Edwards \& Tobias 1993; Edwards et al. 1996; volume 10 on line).

Spelling errors or variants: Actinothö̈

Currently considered valid: Yes

Adamsia Forbes, 1840

Type species: Actinia maculata Adams, 1800, by original designation.

Nomenclature notes: Type species is not in agreement with Carlgren (1949). Authorship is in agreement with Carlgren (1949). In agreement with Neave (1939a), senior homonym of gastropod genus Adamsia of Dunker, G., 1857, Mollusca nova collectionis Cumingianæ. Proceedings of the Zoological Society of London 24:357. Authorship of both genera is in agreement with Neave (1939a).

Currently considered valid: Yes

Aegeon Gosse, 1865

Type species: Ageon Alfordi Gosse, 1865, by monotypy.

Nomenclature notes: In agreement with Neave (1939a), junior homonym of crustacean genus Aegeon of Risso in Kinahan, J. R., 1862, Synopsis of the species of the families Crangonidæ and Galatheidæ which inhabit the seas around the British Isles. Proceedings of the Royal Irish Academy 8:69-70. Authorship of both genera is in agreement with Neave (1939a).

Spelling errors or variants: Ageon

Currently considered valid: No

Aegir Danielssen, 1887

Type species: Agir frigidus Danielssen, 1887, by monotypy.

Nomenclature notes: Authorship is in agreement with Neave (1939).

Spelling errors or variants: Agir

Currently considered valid: No

Aiptasia Gosse, $1858 \mathrm{~b}$

Type species: Aiptasia amacha Gosse, 1858b, by monotypy.

Nomenclature notes: Type species is not in agreement with Carlgren (1949). Authorship is in agreement with Neave (1939a) and with Carlgren (1949).

Spelling errors or variants: Aipstasia

Currently considered valid: Yes

Aiptasiogeton Schmidt, 1972

Type species: Paractis comata Andres, 1881, by monotypy. 
Nomenclature notes: Authorship is in agreement with Edwards and Tobias (1993).

Currently considered valid: Yes

Aiptasioides Stephenson, 1918a

Type species: Aiptasioides prima Stephenson, 1918a, by original designation.

Nomenclature notes: Authorship is in agreement with Neave (1939a).

Currently considered valid: No

Aiptasiomorpha Stephenson, 1920

Type species: Aiptasia minima Stephenson, 1918a, by subsequent designation.

Nomenclature notes: Type species was designated by Carlgren (1949). Authorship is in agreement with Neave (1939) and with Carlgren (1949).

Spelling errors or variants: Aiptasiamorpha, Aiptasimorpha

Currently considered valid: Yes

Alfredus Schmidt, 1979

Type species: Edwardsia lucifuga Fischer, 1888, by original designation.

Nomenclature notes: Authorship is in agreement with Edwards et al. (1996).

Currently considered valid: No

Alicia Johnson, 1861

Type species: Alicia mirabilis Johnson, 1861, by monotypy.

Nomenclature notes: Type species and authorship are in agreement with Carlgren (1949). In agreement with Neave (1939a), senior homonym of [1] coleopteran genus Alicia of Thomson, J., 1864, Systema Cerambycidarum ou Exposé de Tous les Genres Compris dans la Famille des Cérambycides et Familles Limitrophes, page 125; and [2] bivalve genus Alicia of Angas, G. F., 1868, On a new genus and some new species of marine Mollusca from Port Jackson, New South Wales. Proceedings of the Scientific Meetings of the Zoological Society of London 1867:908. Authorship of all genera is in agreement with Neave (1939a).

Currently considered valid: Yes

Allantactis Danielssen, 1890

Type species: Allantactis parasitica Danielssen, 1890, by monotypy.

Nomenclature notes: Authorship is in agreement with Neave (1939a) and with Carlgren (1949).

Spelling errors or variants: Altantactis

Currently considered valid: Yes

Alloactis Verrill, 1899c

Type species: Paractis excavata Hertwig, 1882, by original designation.

Nomenclature notes: Authorship is in agreement with Neave (1939a).

Currently considered valid: No

Ammodiscus Carpenter and Jeffreys, 1871

Type species: Ammodiscus Lindahli Carpenter and Jeffreys, 1871, by monotypy.

Nomenclature notes: Junior homonym of protist genus Ammodiscus of Reuss, A. E., 1862, Entwurf einer systematischen Zusammenstellung der Foraminiferen. Sitzungsberichte der Kaiserlichen Akademie der Wissenschaften 44:365. Authorship of protist genus is in agreement with Neave (1939a). Actiniarian genus is not listed in NZ (Neave 1939a, b, 1940a, b, 1950; Edwards \& Hopwood 1966; Edwards \& Vevers 1975; Edwards \& Tobias 1993; Edwards et al. 1996; volume 10 on line). Fowler (1894) created the replacement name (ICZN Article 60.2) Octineon, attributing it to Moseley.

Currently considered valid: No

Ammonactis Verrill, 1865

Type species: Edwardsia rubricollum Stimpson, 1856a, by monotypy.

Nomenclature notes: Authorship is in agreement with Neave (1939a).

Currently considered valid: No 
Ammophilactis Verrill, 1899c

Type species: Actinia rapiformis Le Sueur, 1817, by original designation.

Nomenclature notes: Authorship is in agreement with Neave (1939a).

Currently considered valid: No

Amphiactis Verrill, 1869b

Type species: Amphiactis orientalis Verrill, 1869b, by monotypy.

Nomenclature notes: In agreement with Neave (1939a), senior homonym of echinoderm genus Amphiactis of Matsumoto, H., 1915, A new classification of the Ophiuroidea: with descriptions of new genera and species. Proceedings of the Academy of Natural Sciences of Philadelphia 67:66-67. Authorship of both genera is in agreement with Neave (1939a). Currently considered valid: Yes

Amphianthus Hertwig, 1882

Type species: Amphianthus bathybium Hertwig, 1882, by monotypy.

Nomenclature notes: Type species is in agreement with Carlgren (1949). Authorship is in agreement with Neave (1939a) and with Carlgren (1949).

Spelling errors or variants: Amphiantus

Currently considered valid: Yes

Andresia Stephenson, 1921

Type species: Ilyanthus partenopeus Andres, 1883, by monotypy.

Nomenclature notes: Authorship is in agreement with Carlgren (1949). Senior homonym of [1] polychaete genus Andresia of Prenant, A., 1924, Andresia ampullifera nov. g., nov. sp. de la sous-famille des polynoïniens. Bulletin de la Société Zoologique de France 49:19; and [2] crustacean genus Andresia of Hinz-Schallreuter, I., 1993, Cambrian ostracodes mainly from Baltoscandia and Morocco. Archiv für Geschiebekunde 1(7):424-425. Actiniarian genus not listed in NZ (Neave 1939a, b, 1940a, b, 1950; Edwards \& Hopwood 1966; Edwards \& Vevers 1975; Edwards \& Tobias 1993; Edwards et al.; volume 10 on line). Authorship of polychaete is in agreement with Neave (1939a), and of ostracode with NZ 10 (on line).

Currently considered valid: Yes

Andvakia Danielssen, 1890

Type species: Andvakia mirabilis Danielssen, 1890, by monotypy.

Nomenclature notes: Type species is in agreement with Carlgren (1949), who spelled the genus Andwakia, which is an incorrect subsequent spelling (ICZN Article 33c). Authorship is in agreement with Neave (1939a) and with Carlgren (1949).

Spelling errors or variants: Andwakia

Currently considered valid: Yes

Anemonactis Andres, 1881

Type species: Anemonactis magnifica Andres, 1881, by monotypy.

Nomenclature notes: Type species is not in agreement with Carlgren (1949), who erroneously gave 1880 as the date of publication; not listed in NZ (Neave 1939a, b, 1940a, b, 1950; Edwards \& Hopwood 1966; Edwards \& Vevers 1975; Edwards \& Tobias 1993; Edwards et al. 1996; volume 10 on line).

Currently considered valid: Yes

Anemonia Risso, 1826

Type species: Actinia sulcata Pennant, 1777, by subsequent designation.

Nomenclature notes: Type species was designated by Carlgren (1949), who erroneously gave 1766 as the date of publication. Authorship is in agreement with Neave (1939a) and with Carlgren (1949).

Spelling errors or variants: Anenomia

Currently considered valid: Yes

Anthea Johnston, 1838

Type species: None 
Nomenclature notes: No type species has been designated for this genus; two species were included in it originally. According to Eschmeyer, W., 1998, Catalog of Fishes, vol. 3 fish genus Anthea of Catesby, 1771, is not available: it was published in a work rejected for nomenclatorial purposes in Opinion 259 of the International Commission on Zoological Nomenclature (Bulletin of Zoological Nomenclature 5:253-264; August 1954) because the author did not apply the principles of binominal nomenclature. Neave (1939a) erroneously gave the date of Catesby as 1777 . Authorship of the actiniarian genus is in agreement with Neave (1939a).

Currently considered valid: No

Antheomorphe Hertwig, 1882

Type species: Antheomorphe elegans Hertwig, 1882, by monotypy.

Nomenclature notes: Authorship is in agreement with Neave (1939a).

Currently considered valid: Yes

Antheopsis Simon, 1892

Type species: Bunodes koseirensis Klunzinger, 1877, by monotypy.

Nomenclature notes: Authorship is in agreement with Neave (1939a).

Currently considered valid: Yes

Antholoba Hertwig, 1882

Type species: Actinia reticulata Couthouy in Dana, 1846, by monotypy.

Nomenclature notes: Type species is not in agreement with Carlgren (1949). Authorship is in agreement with Neave (1939a) and with Carlgren (1949).

Currently considered valid: Yes

Anthopleura Duchassaing de Fonbressin and Michelotti, 1860

Type species: Anthopleura Krebsi Duchassaing de Fonbressin and Michelotti, 1860, by monotypy.

Nomenclature notes: Type species is in agreement with Carlgren (1949). Authorship is in agreement with Neave (1939a) and with Carlgren (1949).

Spelling errors or variants: Anthpleura

Currently considered valid: Yes

Anthosactis Danielssen, 1890

Type species: Anthosactis Jan Mayeni Danielssen, 1890, by monotypy.

Nomenclature notes: Type species is in agreement with Carlgren (1949). Authorship is in agreement with Neave (1939a) and with Carlgren (1949).

Spelling errors or variants: Antosactis

Currently considered valid: Yes

Anthostella Carlgren, 1938

Type species: Anthostella stephensoni Carlgren, 1938, by monotypy.

Nomenclature notes: Type species is in agreement with Carlgren (1949). Authorship is in agreement with Neave (1950) and with Carlgren (1949).

Currently considered valid: Yes

Anthothoe Carlgren, 1938

Type species: Cereus Stimpsonii Verrill, 1869b, by replacement.

Nomenclature notes: Replacement name (ICZN Article 60.2) for the junior homonym Parathoe. Type species is in agreement with Carlgren (1949), who erroneously gave 1868 as the date of publication. Authorship is in agreement with Neave (1950) and with Carlgren (1949).

Spelling errors or variants: Anthothö̈

Currently considered valid: Yes

Antiparactis Verrill, 1899c

Type species: Actinia lineolata Couthouy in Dana, 1846, by monotypy. 
Nomenclature notes: Authorship is in agreement with Neave (1939a) and with Carlgren (1949).

Currently considered valid: Yes

Archactis Verrill, 1899c

Type species: Urticina perdix Verrill, 1882, by original designation.

Nomenclature notes: Described as a subgenus. Authorship is in agreement with Neave (1939a).

Currently considered valid: No

Artemidactis Stephenson, 1918a

Type species: Artemidactis victrix Stephenson, 1918a, by original designation.

Nomenclature notes: Authorship is in agreement with Neave (1939a) and with Carlgren (1949).

Currently considered valid: Yes

Asteractis Verrill, 1869a

Type species: Asteractis Bradleyi Verrill, 1869a, by monotypy.

Nomenclature notes: Authorship is in agreement with Neave (1939a).

Currently considered valid: No

Aulactinia Agassiz in Verrill, 1864a

Type species: Aulactinia capitata Agassiz in Verrill, 1864a, by monotypy.

Nomenclature notes: Authorship is in agreement with Neave (1939a).

Currently considered valid: Yes

Aulorchis Hertwig, 1888

Type species: Aulorchis paradoxa Hertwig, 1888, by monotypy.

Nomenclature notes: Authorship is in agreement with Neave (1939a).

Currently considered valid: No

Aureliania Gosse, 1860

Type species: Corynactis heterocera Thompson, 1853, by subsequent designation.

Nomenclature notes: Type species was designated by Carlgren (1949). Authorship is in agreement with Neave (1939a) and with Carlgren (1949), who erroneously spelled the genus Aureliana.

Spelling errors or variants: Aureliana

Currently considered valid: No

Austroneophellia Zamponi, 1978a

Type species: Austroneophellia luciae Zamponi, 1978a, by original designation.

Nomenclature notes: Authorship is in agreement with Edwards et al. (1996).

Currently considered valid: Yes

Bartholomea Duchassaing de Fombressin and Michelotti, 1864

Type species: Actinia annulata Le Sueur, 1817, by subsequent designation.

Nomenclature notes: Type species was designated by Stephenson (1920) and is in agreement with Carlgren (1949).

Authorship is in agreement with Neave (1939a); Carlgren erroneously gave 1866 as the date of publication.

Currently considered valid: Yes

Bathydactylus Carlgren, 1928a

Type species: Bathydactylus valdiviae Carlgren, 1928a, by monotypy.

Nomenclature notes: Authorship is in agreement with Neave (1939a) and with Carlgren (1949).

Currently considered valid: Yes

Bathyphellia Carlgren, 1932

Type species: Phellia margaritacea Danielssen, 1890, by monotypy. 
Nomenclature notes: Authorship is in agreement with Neave (1940b) and with Carlgren (1949).

Currently considered valid: Yes

Bellactis Dube, 1983

Type species: Bellactis ilkalyseae Dube, 1983, by original designation.

Nomenclature notes: Not listed in NZ (Neave 1939a, b, 1940a, b, 1950; Edwards \& Hopwood 1966; Edwards \& Vevers 1975; Edwards \& Tobias 1993; Edwards et al. 1996; volume 10 on line).

Currently considered valid: Yes

Bicidiopsis Verrill, 1922

Type species: None

Nomenclature notes: No type species has been designated for this genus; two species were included in it originally. Authorship is in agreement with Neave (1939a).

Currently considered valid: No

Bicidium Agassiz, 1859

Type species: Bicidium parasiticum Agassiz, 1859, by monotypy.

Nomenclature notes: Authorship is in agreement with Neave (1939a).

Currently considered valid: Yes

Bolocera Gosse, 1860

Type species: Actínia Tuèdia Johnston, 1832, by monotypy.

Nomenclature notes: Type species is in agreement with Carlgren (1949). In agreement with Neave (1939a), senior homonym of lepidopteran genus Bolocera of Kirby, W. F., 1892, A Synonymic Catalogue of Lepidoptera Heterocera. (Moths.), page 744, which is a misspelling of Holocera as noted in Berg, C., 1899, Observaciones sobre lepidópteros Argentinos y otros Sudamericanos. Anales del Museo Nacional de Buenos Aires, series 2, 6:38. Authorship is in agreement with Neave (1939a) and with Carlgren (1949).

Spelling errors or variants: Bulocera

Currently considered valid: Yes

Boloceractis Panikkar, 1937

Type species: Boloceractis gopalai Panikkar, 1937, by original designation.

Nomenclature notes: Authorship is in agreement with Neave (1950) and with Carlgren (1949).

Currently considered valid: Yes

Boloceroides Carlgren, 1899a

Type species: Bolocera mc murrichi Kwietniewski, 1898, by original designation.

Nomenclature notes: Type species is in agreement with Carlgren (1949). Authorship is in agreement with Neave (1939a) and with Carlgren (1949).

Currently considered valid: Yes

Boloceropsis McMurrich, 1904

Type species: Boloceropsis platei McMurrich, 1904, by monotypy.

Nomenclature notes: Authorship is in agreement with Neave (1939a) and with Carlgren (1949).

Currently considered valid: Yes

Botryon Carlgren and Hedgpeth, 1952

Type species: Botryon tuberculatus Carlgren and Hedgpeth, 1952, by monotypy.

Nomenclature notes: Authorship is in agreement with Edwards and Hopwood (1966).

Currently considered valid: Yes

Bunodactis Verrill, 1899a

Type species: Actinia Verrucosa Pennant, 1777, by original designation.

Nomenclature notes: Type species is in agreement with Carlgren (1949). Authorship is in agreement with Neave (1939a) 
and with Carlgren (1949).

Spelling errors or variants: Bonodactis

Currently considered valid: Yes

Bunodella Pfeffer, 1889

Type species: Bunodella georgiana Pfeffer, 1889, by monotypy.

Nomenclature notes: In agreement with Neave (1939a), junior homonym of xiphosuran genus Bunodella of Matthew, G. F., 1889, On some remarkable organisms of the Silurian and Devonian rocks in southern New Brunswick. Proceedings and Transactions of the Royal Society of Canada 6(4):56. In agreement with Neave (1939a), senior homonym of actiniarian genus Bunodella Verrill, 1899a. Authorship of the actiniarian genera is in agreement with Neave (1939a); Neave erroneously gave 1888 for the Matthew genus.

Currently considered valid: No

Bunodella Verrill, 1899a

Type species: Aulactinia stelloides McMurrich, 1889a, by original designation.

Nomenclature notes: In agreement with Neave (1939a), junior homonym of [1] xiphosuran genus Bunodella of Matthew, G. F., 1889, On some remarkable organisms of the Silurian and Devonian rocks in southern New Brunswick. Proceedings and Transactions of the Royal Society of Canada 6(4):56; and [2] actiniarian genus Bunodella Pfeffer, 1889. Authorship of the actiniarian genera is in agreement with Neave (1939a); Neave erroneously gave 1888 for the Matthew genus.

Currently considered valid: No

Bunodeopsis Andres, 1881

Type species: Bunodeopsis strumosa Andres, 1881, by monotypy.

Nomenclature notes: Type species is in agreement with Carlgren (1949), who erroneously gave 1880 as the date of publication. Authorship is in agreement with Neave (1939a) but not with Carlgren (1949), who erroneously gave 1880 as the date of publication.

Currently considered valid: Yes

Bunodes Gosse, 1855

Type species: Actinia gemmacea Ellis and Solander, 1786, by subsequent designation.

Nomenclature notes: Type species was designated by Haddon (1889). In agreement with Neave (1939a), junior homonym of xiphosuran genus Bunodes of Eichwald C. E., 1854, Die Grauwackenschichten von Live- und Esthland. Bulletin de la Société Impériale des Naturalistes de Moscou 27(1):107-108. Authorship of both genera is agreement with Neave (1939a).

Currently considered valid: Yes

\section{Bunodosoma Verrill, 1899a}

Type species: Actinia granulifera Le Sueur, 1817, by original designation.

Nomenclature notes: Type species is in agreement with Carlgren (1949). Authorship is in agreement with Neave (1939a) and with Carlgren (1949).

Spelling errors or variants: Bunodosma

Currently considered valid: Yes

Cactosoma Danielssen, 1890

Type species: Cactosoma abyssorum Danielssen, 1890, by monotypy.

Nomenclature notes: Type species is in agreement with Carlgren (1949). Authorship is in agreement with Neave (1939a) and with Carlgren (1949).

Spelling errors or variants: Castosoma

Currently considered valid: Yes

Calamactinia Carlgren, 1949

Type species: Calamactinia goughiensis Carlgren, 1949, by monotypy.

Nomenclature notes: Authorship is in agreement with Edwards and Hopwood (1966). Interpreted as available under 
ICZN Article 13(c) by Fautin (1998).

Currently considered valid: Yes

Calamactis Carlgren, 1951

Type species: Calamactis praelongus Carlgren, 1951, by monotypy.

Nomenclature notes: Edwards and Hopwood (1966) stated the genus was described by Carlgren in 1949. The name

Calamactis as published by Carlgren in 1949, is a nomen nudum: it is unavailable under ICZN Article 13.3.1 because the single included species, Calamactis praelongus, is a nomen nudum, being unavailable under ICZN Article 13.1.1.

Currently considered valid: Yes

Calliactis Verrill, 1869a

Type species: Actinia decorata Couthouy in Dana, 1846, by original designation.

Nomenclature notes: Type species is in agreement with Carlgren (1949). Authorship is in agreement with Neave (1939a) and with Carlgren (1949).

Spelling errors or variants: Calliactus

Currently considered valid: Yes

Cancrisocia Stimpson, 1856a

Type species: Cancrisocia expansa Stimpson, 1856a, by monotypy.

Nomenclature notes: Neave (1939a) erroneously gave 1855 as the date of publication.

Currently considered valid: No

Capnea Forbes, 1841

Type species: Capnea sanguinea Forbes, 1841, by monotypy.

Nomenclature notes: Neave (1939b) stated the genus should be spelled Kapnea. Acting as First Reviser (ICZN Article 24.2.1), Dunn (1983) chose to follow majority usage in spelling the genus Capnea.

Spelling errors or variants: Kapnea

Currently considered valid: Yes

Capneopsis Duchassaing de Fombressin and Michelotti, 1864

Type species: Capneopsis Solidago Duchassaing de Fombressin and Michelotti, 1864, by monotypy.

Nomenclature notes: Authorship is in agreement with Neave (1939a).

Currently considered valid: No

Carcinactis Uchida, 1960

Type species: Carcinactis ichikawai Uchida, 1960, by original designation.

Nomenclature notes: Authorship is in agreement with Edwards and Vevers (1975).

Currently considered valid: Yes

Carlgrenia Stephenson, 1918b

Type species: Carlgrenia desiderata Stephenson, 1918b, by monotypy.

Nomenclature notes: Authorship is in agreement with Neave (1939a) and with Carlgren (1949).

Currently considered valid: Yes

Carlgreniella Watzl, 1922

Type species: Carlgreniella robusta Watzl, 1922, by monotypy.

Nomenclature notes: Authorship is in agreement with Neave (1939a).

Currently considered valid: No

Catadiomene Stephenson, 1920

Type species: None

Nomenclature notes: No type species has been designated for this genus; three species were included in it originally. Authorship is in agreement with Neave (1939a).

Currently considered valid: No 
Cataphellia Stephenson, 1929

Type species: Phellia Brodricii Gosse, 1859, by original designation.

Nomenclature notes: Authorship is in agreement with Neave (1939a) and with Carlgren (1949).

Currently considered valid: Yes

Ceratactis Milne Edwards, 1857

Type species: None

Nomenclature notes: No type species has been designated for this genus; two species were included in it originally. Authorship is in agreement with Neave (1939a).

Currently considered valid: No

Cereactis Andres, 1881

Type species: Actinia aurantiaca Delle Chiaje, 1825, by monotypy.

Nomenclature notes: Not listed in NZ (Neave 1939a, b, 1940a, b, 1950; Edwards \& Hopwood 1966; Edwards \& Vevers 1975; Edwards \& Tobias 1993; Edwards et al. 1996; volume 10 on line).

Currently considered valid: No

Charisea Torrey, 1902

Type species: Charisea saxicola Torrey, 1902, by monotypy.

Nomenclature notes: Authorship is in agreement with Neave (1939) and with Carlgren (1949).

Currently considered valid: Yes

Charisella Carlgren, 1950a

Type species: Charisella elongata Carlgren, 1950a, by original designation.

Nomenclature notes: In agreement with Neave (1950) and Edwards and Hopwood (1966), junior homonym of fish genus Charisella of Fowler, W. H., 1939, Zoological results of the Denison-Crockett South Pacific Expedition for the Academy of Natural Sciences of Philadelphia, 1937-1938. Part III-the fishes, Proceedings of the Academy of Natural Sciences of Philadelphia 91:90-91. Edwards and Hopwood (1966) stated the genus was described by Carlgren in 1949. The name Charisella as published by Carlgren in 1949 is a nomen nudum: it is unavailable under ICZN Article 13.3.1 because the originally designated type species, Charisella elongata, is a nomen nudum, being unavailable under ICZN Article 13.1.1. Currently considered valid: Yes

Chermadion Pax, 1924

Type species: Chermadion chinense Pax, 1924, by monotypy.

Nomenclature notes: Not listed in NZ (Neave 1939a, b, 1940a, b, 1950; Edwards \& Hopwood 1966; Edwards \& Vevers 1975; Edwards \& Tobias 1993; Edwards et al. 1996; volume 10 on line).

Currently considered valid: No

Chitonactis Fischer, 1874

Type species: Bunodes coronata Gosse, 1858a, by monotypy.

Nomenclature notes: Authorship is in agreement with Neave (1939a).

Spelling errors or variants: Chitonactes

Currently considered valid: No

Chitonanthus McMurrich, 1893

Type species: Phellia pectinata Hertwig, 1882, by monotypy.

Nomenclature notes: Authorship is in agreement with Neave (1939a).

Currently considered valid: Yes

Chondractinia Lütken, 1861

Type species: Actinia digitata Müller, 1776, by monotypy.

Nomenclature notes: Authorship is in agreement with Neave (1939a).

Spelling errors or variants: Chondrachtinia

Currently considered valid: No 
Chondranthus Migot and Portmann, 1926

Type species: Chondranthus denudatum Migot and Portmann, 1926, by monotypy.

Nomenclature notes: Authorship is in agreement with Neave (1939a).

Currently considered valid: Yes

Chondrodactis Wassilieff, 1908

Type species: None

Nomenclature notes: No type species has been designated for this genus; three species were included in it originally. Authorship is in agreement with Neave (1939a).

Currently considered valid: No

Chondrophellia Carlgren, 1925a

Type species: Actinauge nodosa Verrill, 1883, by monotypy.

Nomenclature notes: Type species is in agreement with Carlgren (1949). Authorship is in agreement with Neave (1939a) and with Carlgren (1949).

Spelling errors or variants: Chondrophella

Currently considered valid: Yes

Choriactis McMurrich, 1904

Type species: Actinia impatiens Couthouy in Dana, 1846, by subsequent designation.

Nomenclature notes: Type species was designated by Stephenson (1920), in agreement with Carlgren (1949). Neave (1939a) gave 1905 for the genus; there is evidence that publication was in 1904, which is the date given by Carlgren (1949).

Currently considered valid: Yes

Chrysoela Stephenson, 1935

Type species: Actinia chrysosplenium W.P. Cocks in Johnston, 1847, by monotypy.

Nomenclature notes: Not listed in NZ (Neave 1939a, b, 1940a, b, 1950; Edwards \& Hopwood 1966; Edwards \& Vevers 1975; Edwards \& Tobias 1993; Edwards et al. 1996; volume 10 on line ).

Currently considered valid: Yes

Cladactella Verrill, 1928

Type species: Bunodactis Manni Verrill, 1899c, by subsequent designation.

Nomenclature notes: Type species was designated by Carlgren (1949). Authorship is in agreement with Neave (1939a) and with Carlgren (1949).

Currently considered valid: Yes

Cladactis Panceri, 1868

Type species: Cladactis costa Panceri, 1868, by monotypy.

Nomenclature notes: In agreement with Neave (1939a), junior homonym of echinoderm genus Cladactis of Rafinesque, C. S., 1815, Analyse de la Nature, 153. In agreement with Neave (1939a), senior homonym of actiniarian genus Cladactis of Verrill, 1869a. Authorship of the echinoderm genus and of Verrill's genus are in agreement with Neave (1939a), but Neave erroneously gave the date of the genus described by Panceri as 1869.

Currently considered valid: No

Cladactis Verrill, 1869a

Type species: Cladactis grandis Verrill, 1869a, by monotypy.

Nomenclature notes: In agreement with Neave (1939a), junior homonym of [1] echinoderm genus Cladactis of Rafinesque, C. S., 1815, Analyse de la Nature, page 153; and [2] actiniarian genus Cladactis of Panceri, 1868. Verrill (1899a) created the replacement name (ICZN Article 60.2) Eucladactis for this genus. Authorship of echinoderm genus and of Verrill's genus are in agreement with Neave (1939a), but Neave erroneously gave the date of the genus described by Panceri as 1869 .

Currently considered valid: No 
Cnidanthea Carlgren, 1959

Type species: Cnidanthea maculata Carlgren, 1959, by monotypy.

Nomenclature notes: Authorship is in agreement with Edwards and Vevers (1975).

Currently considered valid: Yes

Cnidanthus Carlgren, 1927

Type species: Paractis polaris Clubb, 1908, by monotypy.

Nomenclature notes: Authorship is in agreement with Neave (1939a) and with Carlgren (1949).

Currently considered valid: Yes

Cnidopus Carlgren, 1934b

Type species: Epiactis ritteri Torrey, 1902, by monotypy.

Nomenclature notes: Authorship is in agreement with Neave (1939a) and with Carlgren (1949).

Currently considered valid: Yes

Comactis Milne Edwards, 1857

Type species: None

Nomenclature notes: No type species has been designated for this genus; two species were included in it originally. Authorship is in agreement with Neave (1939a).

Currently considered valid: No

Condylactis Duchassaing de Fombressin and Michelotti, 1864

Type species: Condylactis passiflora Duchassaing de Fombressin and Michelotti, 1864, by monotypy.

Nomenclature notes: Type species is not in agreement with Carlgren (1949). Authorship is in agreement with Neave (1939a) but not with Carlgren (1949), who erroneously gave 1866 as the date of publication.

Spelling errors or variants: Codylactis

Currently considered valid: Yes

Condylanthus Carlgren, 1899b

Type species: Condylanthus magellanicus Carlgren, 1899b, by monotypy.

Nomenclature notes: Type species is in agreement with Carlgren (1949). Neave (1939a) gave the date as 1898; there is evidence that publication was in 1899, the date given by Carlgren (1949).

Currently considered valid: Yes

Cradactis McMurrich, 1893

Type species: Cradactis digitata McMurrich, 1893, by monotypy.

Nomenclature notes: Authorship is in agreement with Neave (1939a).

Currently considered valid: No

Crambactis Haeckel, 1876

Type species: Crambactis arabica Haeckel, 1876, by monotypy.

Nomenclature notes: Neave (1939a) gave 1875 for the genus but 1876 for the publication.

Spelling errors or variants: Crambractis

Currently considered valid: No

Cribrina Hemprich and Ehrenberg in Ehrenberg, 1834

Type species: Priapus polypus Forsskål, 1775, by subsequent designation.

Nomenclature notes: Type species was designated by Haddon (1889). Authorship is in agreement with Neave (1939a).

Spelling errors or variants: Cribina

Currently considered valid: Yes

Cribrinopsis Carlgren, 1921

Type species: Cribrinopsis similis Carlgren, 1921, by monotypy.

Nomenclature notes: Type species is in agreement with Carlgren (1949). Neave (1939a) erroneously gave the date as 
1922; Carlgren (1949) gave the date as 1921.

Currently considered valid: Yes

Cricophorus Carlgren, 1924a

Type species: Sagartia nutrix Stuckey, 1909, by monotypy.

Nomenclature notes: In agreement with Neave (1939a), junior homonym of gastropod genus Cricophorus Kobelt, W. and O. Moellendorff, 1897, Catalog der gegenwärtig lebend bekannten Pneumonopomen. Nachrichtenblatt der Deutschen Malakozoologischen Gesellschaft, 29:111. Authorship of the actiniarian genus is in agreement with Carlgren (1949); that of both genera is in agreement with Neave (1939a).

Currently considered valid: Yes

Cryptodendrum Klunzinger, 1877

Type species: Cryptodendrum adhäsivum Klunzinger, 1877, by monotypy.

Nomenclature notes: Type species is in agreement with Dunn (1981). Authorship is in agreement with Neave (1939a) and with Carlgren (1949).

Spelling errors or variants: Criptodendrum, Cryptodendron

Currently considered valid: Yes

Cyananthea Doumenc and Van-Praët, 1988

Type species: Cyananthea hydrothermala Doumenc and Van-Praët, 1988, by monotypy.

Nomenclature notes: Not listed in NZ (Edwards et al. 1996; volume 10 on line).

Spelling errors or variants: Cyanthea, Cyanththea

Currently considered valid: Yes

Cylista Wright, 1859

Type species: None

Nomenclature notes: No type species has been designated for this genus; three species were included in it originally.

Neave (1939a) erroneously stated the genus was described by Gosse in 1860.

Currently considered valid: No

Cymbactis McMurrich, 1893

Type species: Cymbactis faeculenta McMurrich, 1893, by monotypy.

Nomenclature notes: Authorship is in agreement with Neave (1939a).

Currently considered valid: No

Cyrtactis Thompson, 1858

Type species: None

Nomenclature notes: Authorship is in agreement with Neave (1939a). Genus name is a nomen dubium because the type species Actinia clavata is ambiguous: it was described twice, as A. clavata Ilmoni, 1830 and A. clavata Rathke, 1843.

Currently considered valid: No

Cystiactis Milne Edwards, 1857

Type species: None

Nomenclature notes: No type species has been designated for this genus; three species were included in it originally. Authorship is in agreement with Neave (1939a).

Currently considered valid: Yes

Dactylanthus Carlgren, 1911

Type species: Cystiactis antarctica Clubb, 1908, by original designation.

Nomenclature notes: According to Neave (1939b), senior homonym of echinoderm genus Dactylanthus of Lambert, J., 1912 [not seen; given as “Mém. Soc. Pal. Suisse, 38, Ech. néog. Rhône, 89.”]. Authorship of the actiniarian genus is in agreement with Neave (1939b) and with Carlgren (1949).

Currently considered valid: Yes 
Dactylominyas Andres, 1883

Type species: None

Nomenclature notes: No type species has been designated for this genus; three species were included in it originally.

Authorship is in agreement with Neave (1939b).

Spelling errors or variants: dactylominyas

Currently considered valid: No

Daontesia Carlgren, 1942

Type species: Sagartiogeton praelongus Carlgren, 1928b, by monotypy.

Nomenclature notes: Authorship is in agreement with Edwards and Hopwood (1966) and with Carlgren (1949).

Currently considered valid: Yes

Decaphellia Bourne, 1918

Type species: Decaphellia psammomitra Bourne, 1918, by monotypy.

Nomenclature notes: Authorship is in agreement with Neave (1939b) and with Carlgren (1949).

Currently considered valid: Yes

Dendractis Andres, 1883

Type species: Actinia Priapus Tilesius, 1809, by monotypy.

Nomenclature notes: Not listed in NZ (Neave 1939a, b, 1940a, b, 1950; Edwards \& Hopwood 1966; Edwards \& Vevers 1975; Edwards \& Tobias 1993; Edwards et al. 1996; volume 10 on line).

Currently considered valid: No

Diactis Hutton, 1879

Type species: Diactis crocata Hutton, 1879, by monotypy.

Nomenclature notes: Not listed in NZ (Neave 1939a, b, 1940a, b, 1950; Edwards \& Hopwood 1966; Edwards \& Vevers 1975; Edwards \& Tobias 1993; Edwards et al. 1996; volume 10 on line). Senior homonym of myriapod genus Diactis of Loomis, H. F., 1937, Crested millipeds of the family Lysiopetalidae in North America, with descriptions of new genera and species. Proceedings of the United States National Museum 84:110-111. Authorship of myriapod genus is in agreement with Edwards and Tobias (1993).

Currently considered valid: No

Diadumene Stephenson, 1920

Type species: Sagartia Schilleriana Stoliczka, 1869, by monotypy.

Nomenclature notes: Type species is in agreement with Carlgren (1949). Authorship is in agreement with Neave (1939b) and with Carlgren (1949).

Spelling errors or variants: Diadumine, diadumene

Currently considered valid: Yes

Dimyactis Pax, 1922

Type species: Dimyactis duplicata Pax, 1922, by monotypy.

Nomenclature notes: Authorship is in agreement with Neave (1939b).

Currently considered valid: No

Diphtera Sluiter, 1888

Type species: Diphtera oktoplax Sluiter, 1888, by monotypy.

Nomenclature notes: According to Neave (1939b), junior homonym of lepidopteran Diphtera of Ochsenheimer, 1816 [not seen; given as "Schmett. Europa, 4, 63”]. Actiniarian genus not listed in NZ (Neave 1939a, b, 1940a, b, 1950; Edwards \& Hopwood 1966; Edwards \& Vevers 1975; Edwards \& Tobias 1993; Edwards et al. 1996; volume 10 on line).

Currently considered valid: No

Diplactis McMurrich, 1889b

Type species: None

Nomenclature notes: No type species has been designated for this genus; two species were included in it originally. 
Scleractinian genus Diplactis of Munier-Chalmas in Bernard, F., 1895, Élèments de Plalèntologie, page 176, is a nomen nudum: it is unavailable because it was not accompanied by a description or a definition of the taxon that it denoted (ICZN Article 12.1). Authorship of both genera is in agreement with Neave (1939b).

Currently considered valid: No

Dofleinia Wassilieff, 1908

Type species: Dofleinia armata Wassilieff, 1908, by monotypy.

Nomenclature notes: Type species is in agreement with Carlgren (1949). In agreement with NZ 10 (on line), actiniarian is senior homonym of crustacean genus Dofleinia of McLaughlin, P. A. and A. Asakura, 2004, Reevaluation of the hermit crab genus Parapagurodes McLaughlin and Haig, 1973 (Decapoda: Anomura: Paguroidea: Paguridae) and a new genus for Parapagurodes doederleini (Doflein, 1902). Proceedings of the Biological Society of Washington 117:54-55. Authorship of the actiniarian genus is in agreement with Neave (1939b) and with Carlgren (1949).

Spelling errors or variants: Doflenia

Currently considered valid: Yes

Drillactis Verrill, 1922

Type species: Edwardsia pallida Verrill, 1880, by original designation.

Nomenclature notes: Not listed in NZ (Neave 1939a, b, 1940a, b, 1950; Edwards \& Hopwood 1966; Edwards \& Vevers 1975; Edwards \& Tobias 1993; Edwards et al. 1996; volume 10 on line). Authorship is in agreement with Carlgren (1949).

Currently considered valid: Yes

Dysactis Milne Edwards, 1857

Type species: None

Nomenclature notes: No type species has been designated for this genus; four species were included in it originally. Authorship is in agreement with Neave (1939b).

Spelling errors or variants: Disactis

Currently considered valid: No

Echinactis Milne Edwards and Haime, 1851

Type species: Sarcophinanthus papillosus Lesson, 1830, by monotypy.

Nomenclature notes: Authorship is in agreement with Neave (1939b).

Currently considered valid: Yes

Ectacmaea Ehrenberg, 1834

Type species: None

Nomenclature notes: Described as a subgenus. No type species has been designated for this genus; two species were included in it originally. Authorship is in agreement with Neave (1939b).

Currently considered valid: No

Edwardsia de Quatrefages, 1842

Type species: Edwardsia Beautempsii de Quatrefages, 1842, by subsequent designation.

Nomenclature notes: Type species was designated by Carlgren (1949), in agreement with Williams (1981). Crustacean genus Edwardsia of Costa, O.-G., 1834 (Cenni Zoologici Ossia Descrizione Sommaria delle Specie Nuove di Animali: 62-63) was suppressed by the International Commission on Zoological Nomenclature for the purpose of both the Principle of Priority and the Principle of Homonymy in Opinion 1294 (Bulletin of Zoological Nomenclature 42:31-33; April 1985). In agreement with Neave (1939b), senior homonym of [1] gastropod genus Edwardsia of Koenen, 1865, Die Fauna der unter-oligocänen Tertiärschichten von Helmstädt bei Braunschweig. Zeitschrift der Deutschen Geologischen Gesellschaft 17:480-481; [2] lepidopteran genus Edwardsia of Neumoegen, B., 1880, Description of a new genus and species of Zygaenidæ. Canadian Entomologist 12:67-68; and [3] lepidopteran genus Edwardsia of Tutt, J. W., 1907, A Natural History of British Lepidoptera 9:144. Authorship of the non-actiniarian genera is in agreement with Neave (1939b), who gave 1841 as the date of de Quatrefages, but there is evidence it was published in 1842, as given by Carlgren (1949). 
Spelling errors or variants: Edwardsa, Edwarsia

Currently considered valid: Yes

Edwardsianthus England, 1987

Type species: Edwardsia pudica Klunzinger, 1877, by original designation.

Nomenclature notes: Not listed in NZ (Edwards et al. 1996; volume 10 on line).

Currently considered valid: Yes

Edwardsiella Andres, 1883

Type species: Edwardsia carnea Gosse, 1856, by subsequent designation.

Nomenclature notes: Type species was designated by Manuel (1981). In agreement with Edwards and Hopwood (1966), Edwards and Vevers (1975), and NZ 10 (on line), senior homonym of [1] scleractinian genus Edwardsiella Rukhin, 1937 [not seen; given by Edwards and Vevers, 1975, as "Upper Silurian Tabulata of the Turkestan mountain range Khan-Tengri:1-99"] for which the replacement name Cylindrostylus was created by Sokolov, 1955 [not seen; give by Edwards and Hopwood, 1966, as “Trud. vses. neft. nauch-issled. Geol. Raz. Inst., N.S. 85, 225"]; and [2] dinoflagellate genus (described under the zoological code) Edwardsiella Versteegh, J. M. and D. Zevenboom, 1995, Review of Palaeobotany and Palynology 85:217-220. Authorship of the actiniarian genus is in agreement with Neave (1939b); authorship of scleractinian is in agreement with Edwards and Vevers (1975).

Currently considered valid: Yes

Edwardsioides Danielssen, 1890

Type species: Edwardsioides vitrea Danielssen, 1890, by monotypy.

Nomenclature notes: Authorship is in agreement with Neave (1939b).

Currently considered valid: No

Eloactis Andres, 1883

Type species: Ilyanthus mazeli Jourdan, 1880, by subsequent designation.

Nomenclature notes: Type species was designated by Haddon (1898). Authorship is in agreement with Neave (1939b).

Currently considered valid: Yes

Eltaninactis Dunn, 1983

Type species: Eltaninactis infundibulum Dunn, 1983, by original designation.

Nomenclature notes: Authorship is in agreement with Edwards et al. (1996).

Currently considered valid: Yes

Endocoelactis Carlgren, 1897

Type species: None

Nomenclature notes: This is a nomen nudum because a species was not assigned to this genus (ICZN Article 12.2.5). The species that was being discussed, without a name, by Carlgren (1897) was named by McMurrich (1901) Halcurias Carlgreni.

Currently considered valid: No

Entacmaea Ehrenberg, 1834

Type species: Actinia quadricolor Leuckart in Rüppell and Leuckart, 1828, by subsequent designation.

Nomenclature notes: Type species was designated by Dunn (1981). Authorship is in agreement with Neave (1939b).

Spelling errors or variants: Entacmea, Entacmaea, entacmaea

Currently considered valid: Yes

Epiactis Verrill, 1869a

Type species: Epiactis prolifera Verrill, 1869a, by monotypy.

Nomenclature notes: Type species is in agreement with Carlgren (1949). Authorship is in agreement with Neave (1939b) and with Carlgren (1949).

Currently considered valid: Yes 
Epicladia Hemprich and Ehrenberg in Ehrenberg, 1834

Type species: Epicladia quadrangula Hemprich and Ehrenberg in Ehrenberg, 1834, by monotypy.

Nomenclature notes: Authorship is in agreement with Neave (1939b).

Currently considered valid: No

Epicystis Ehrenberg, 1834

Type species: Actinia crucifera Le Sueur, 1817, by subsequent designation.

Nomenclature notes: Type species was designated by Verrill (1898). Authorship is in agreement with Neave (1939b).

Currently considered valid: Yes

Epigonactis Verrill, 1899d

Type species: None

Nomenclature notes: No type species has been designated for this genus; two species were included in it originally. Authorship is in agreement with Neave (1939b).

Currently considered valid: No

Epiparactis Carlgren, 1921

Type species: Epiparactis dubia Carlgren, 1921, by monotypy.

Nomenclature notes: Authorship is in agreement with Carlgren (1949); Neave (1939b) erroneously gave 1922 as the date.

Currently considered valid: Yes

Epiphellia Carlgren, 1950a

Type species: Epiphellia anneae Carlgren, 1950a, by original designation.

Nomenclature notes: Edwards and Hopwood (1966) stated the genus was described by Carlgren in 1949. The name Epiphellia as published by Carlgren in 1949 is a nomen nudum: it is unavailable under ICZN Article 13.3.1 because the originally designated type species, Epiphellia anneae, was a nomen nudum, having been unavailable under ICZN Article 13.1.1.

Currently considered valid: Yes

Eubolocera Verrill, 1922

Type species: Bolocera multicornis Verrill, 1880, by original designation.

Nomenclature notes: Authorship is in agreement with Neave (1939b).

Currently considered valid: No

Eucladactis Verrill, 1899a

Type species: Cladactis grandis Verrill, 1869a, by replacement.

Nomenclature notes: Replacement name (ICZN Article 60.2) for the junior homonym Cladactis Verrill, 1869a. Authorship is in agreement with Neave (1939b).

Currently considered valid: No

Eumenides Lesson, 1830

Type species: Eumenides ophiseocoma Lesson, 1830, by monotypy.

Nomenclature notes: Authorship is in agreement with Neave (1939b).

Currently considered valid: No

Euphellia Pax, 1908

Type species: Euphellia cinclidifera Pax, 1908, by monotypy.

Nomenclature notes: Authorship is in agreement with Neave (1939b) and with Carlgren (1949).

Currently considered valid: Yes

Evactis Verrill, 1869a

Type species: Actinia artemisia Pickering in Dana, 1846, by original designation. 
Nomenclature notes: Authorship is in agreement with Neave (1939b) and with Carlgren (1949).

Currently considered valid: No

Exocoelactis Carlgren, 1925b

Type species: Polysiphonia tuberosa Hertwig, 1882, by subsequent designation.

Nomenclature notes: Type species was designated by Carlgren (1949). Authorship is in agreement with Neave (1940b) and with Carlgren (1949).

Currently considered valid: Yes

Fagesia Delphy, 1938

Type species: Milne-edwardsia Lovéni Carlgren, 1893, by original designation.

Nomenclature notes: Type species is in agreement with Carlgren (1949), who erroneously gave 1892 as the date of publication. Junior homonym of cephalopod genus Fagesia of Pervinquière, L., 1907, Études de Palèontologie Tunisienne. I. Cèphalopodes des Terrains Secondaires, pages 319-322. Authorship of cephalopod genus is in agreement with Neave (1939b); actiniarian genus not listed in NZ (Neave 1939a, b, 1940a, b, 1950; Edwards \& Hopwood 1966; Edwards \& Vevers 1975; Edwards \& Tobias 1993; Edwards et al. 1996; volume 10 on line).

Spelling errors or variants: Favesia

Currently considered valid: No

Farsonia Stephenson, 1925

Type species: Diadumene cincta Stephenson, 1925, by monotypy.

Nomenclature notes: Not listed in NZ (Neave 1939a, b, 1940a, b, 1950; Edwards \& Hopwood 1966; Edwards \& Vevers 1975; Edwards \& Tobias 1993; Edwards et al. 1996; volume 10 on line).

Currently considered valid: No

Fenja Danielssen, 1887

Type species: Fenja mirabilis Danielssen, 1887, by monotypy.

Nomenclature notes: Neave (1939b) erroneously gave 1888 as the date of publication.

Currently considered valid: No

Flosmaris Stephenson, 1920

Type species: Flosmaris phellioides Stephenson, 1920, by monotypy.

Nomenclature notes: Authorship is in agreement with Neave (1939b) and with Carlgren (1949).

Currently considered valid: Yes

Galatheanthemum Carlgren, 1956

Type species: Galatheanthemum profundale Carlgren, 1956, by original designation.

Nomenclature notes: Authorship is in agreement with Edwards and Vevers (1975).

Currently considered valid: Yes

Gephyra Koch, 1878

Type species: Gephyra Dohrnii Koch, 1878, by monotypy.

Nomenclature notes: In agreement with Neave (1939b), junior homonym of [1] lepidopteran genus Gephyra of Walker, F., 1859, List of the Specimens of Lepidopterous Insects in the Collecton [sic] of the British Museum, pages 848-849; and [2] arachnid genus Gephyra of Koch, L., 1871, Die Arachniden Australiens nach der Natur Beschrieben und Abgebildet. Actiniarian genus not listed in NZ (Neave 1939a, b, 1940a, b, 1950; Edwards \& Hopwood 1966; Edwards \& Vevers 1975; Edwards \& Tobias 1993; Edwards et al. 1996; volume 10 on line). Authorship of lepidopteran genus is in agreement with Neave (1939b); Neave erroneously gave 1873 for the arachnid genus.

Currently considered valid: No

Gephyropsis Carlgren, 1925a

Type species: Gephyra Dohrnii Koch, 1878, by original designation.

Nomenclature notes: Authorship is in agreement with Neave (1939b).

Currently considered valid: No 
Glandulactis Riemann-Zürneck, 1978

Type species: Actinostola spetsbergensis Carlgren, 1893, by original designation.

Nomenclature notes: Authorship is in agreement with Edwards et al. (1996).

Currently considered valid: No

Gliactis Gravier, 1918

Type species: Gliactis crassa Gravier, 1918, by monotypy.

Nomenclature notes: Authorship is in agreement with Neave (1939b).

Spelling errors or variants: Gliatactis

Currently considered valid: Yes

Glyphoperidium Roule, 1909

Type species: Glyphoperidium bursa Roule, 1909, by monotypy.

Nomenclature notes: Authorship is in agreement with Neave (1939b) and with Carlgren (1949).

Currently considered valid: Yes

Glyphostylum Roule, 1909

Type species: Glyphostylum calyx Roule, 1909, by monotypy.

Nomenclature notes: Authorship is in agreement with Neave (1939b) and with Carlgren (1949).

Currently considered valid: No

Gonactinia Sars, 1851

Type species: Actinia prolifera Sars, 1835, by monotypy.

Nomenclature notes: Neave (1939b) erroneously gave 1850 as the date of publication; Carlgren (1949) gave it correctly.

Spelling errors or variants: Gonactinea

Currently considered valid: Yes

Gregoria Gosse, 1860

Type species: Gregoria fenestrata Gosse, 1860, by monotypy.

Nomenclature notes: Authorship is in agreement with Neave (1939b).

Currently considered valid: Yes

Gymnophellia England, 1992

Type species: Gymnophellia hutchingsae England, 1992, by original designation.

Nomenclature notes: Authorship is in agreement with Edwards et al. (1996).

Currently considered valid: Yes

Gyractis Boveri, 1893

Type species: Gyractis excavata Boveri, 1893, designated here.

Nomenclature notes: Fautin (2005) discussed taxonomic and nomenclatural issues concerning the genus and two species described by Boveri in 1893, noting that the species Gyractis excavata enjoys "position precedence" (ICZN Recommendataion 69A.10); we hereby designate it the type species of Gyractis. Authorship is in agreement with Neave (1939b).

Currently considered valid: Yes

Gyrostoma Kwietniewski, 1897

Type species: Gyrostoma Hertwigi Kwietniewski, 1897, by monotypy.

Nomenclature notes: Type species is in agreement with Carlgren (1949). In agreement with Neave (1939b), junior homonym of [1] hymenopteran genus Gyrostoma of Kirby, W. and W. Spence, 1828, An Introduction to Entomology: or Elements of the Natural History of Insects, edition 5, 3:36; and [2] mollusc genus Gyrostoma of Gray, J. E. 1857, Guide to the Systematic Distribution of Mollusca in the British Museum part 1, page 103. Neave (1939b) listed a mollusc genus Gyrostoma of Hesse, P., 1909, Die systematische Stellung von Helix leachii Fér. und gyrostoma Fér. Zoologische Jahrbücher, Abteilung für Systematik, Geographie und Biologie der Tiere 27:320; however, the name seems to have been applied to a species. Description of the actiniarian repeated (in nearly the same words) by Kwietniewski (1898). Authorship of all genera is in agreement with Neave (1939b); Carlgren (1949) erroneously gave 1898 as the date of the actiniar- 
ian genus.

Spelling errors or variants: Gysostoma

Currently considered valid: Yes

Habrosanthus Cutress, 1961

Type species: Habrosanthus bathamae Cutress, 1961, by original designation.

Nomenclature notes: Authorship is in agreement with Edwards and Vevers (1975).

Currently considered valid: Yes

Hadalanthus Carlgren, 1956

Type species: Hadalanthus knudseni Carlgren, 1956, by monotypy.

Nomenclature notes: Authorship is in agreement with Edwards and Vevers (1975).

Currently considered valid: Yes

Halcampa Gosse, 1858 b

Type species: Actinia chrysanthellum C. W. Peach in Johnston, 1847, by monotypy.

Nomenclature notes: Type species is in agreement with Carlgren (1949). Authorship is in agreement with Neave (1939b) and with Carlgren (1949).

Spelling errors or variants: Halocampa

Currently considered valid: Yes

Halcampactis Farquhar, 1898

Type species: Halcampactis mirabilis Farquhar, 1898, by monotypy.

Nomenclature notes: Type species is in agreement with Carlgren (1949). Authorship is in agreement with Neave (1939b) and with Carlgren (1949).

Spelling errors or variants: Halcompactis

Currently considered valid: Yes

Halcampaster Carlgren, 1938

Type species: Halcampaster teres Carlgren, 1938, by monotypy.

Nomenclature notes: Authorship is in agreement with Carlgren (1949) and with Neave (1950).

Currently considered valid: Yes

Halcampella Andres, 1883

Type species: Halcampa endromitata Andres, 1881, by monotypy.

Nomenclature notes: Type species is in agreement with Carlgren (1949), who erroneously gave 1880 as the date of publication. Authorship is in agreement with Neave (1939b).

Currently considered valid: Yes

Halcampogeton Carlgren, 1937

Type species: Halcampogeton papillosus Carlgren, 1937, by original designation.

Nomenclature notes: Authorship is in agreement with Carlgren (1949) and with Neave (1950).

Currently considered valid: Yes

Halcampoides Danielssen, 1890

Type species: Halcampoides abyssorum Danielssen, 1890, by monotypy.

Nomenclature notes: Authorship is in agreement with Neave (1939b) and with Carlgren (1949).

Currently considered valid: Yes

Halcampomorphe Carlgren, 1893

Type species: Actinia Clavus Quoy and Gaimard, 1833, by original designation.

Nomenclature notes: Authorship is in agreement with Neave (1939b).

Spelling errors or variants: Halcampomorpha

Currently considered valid: No 
Halcurias McMurrich, 1893

Type species: Halcurias pilatus McMurrich, 1893, by monotypy.

Nomenclature notes: Type species is in agreement with Carlgren (1949). Neave (1939b) erroneously gave 1894 as the date of publication; Carlgren (1949) gave it correctly.

Currently considered valid: Yes

Haliactis Carlgren, 1921

Type species: Haliactis arctica Carlgren, 1921, by monotypy.

Nomenclature notes: Neave (1939b) erroneously gave 1922 as the date of publication; Carlgren (1949) gave it correctly.

Currently considered valid: Yes

Halianthella Kwietniewski, 1896b

Type species: Edwardsia Kerguelensis Studer, 1879, by monotypy.

Nomenclature notes: Type species is in agreement with Carlgren (1949), who erroneously gave 1878 as the date of publication. Authorship is in agreement with Neave (1939b) and with Carlgren (1949).

Currently considered valid: Yes

Halianthus Kwietniewski, 1896b

Type species: None

Nomenclature notes: No type species has been designated for this genus; two species were included in it originally. Not listed in NZ (Neave 1939a, b, 1940a, b, 1950; Edwards \& Hopwood 1966; Edwards \& Vevers 1975; Edwards \& Tobias 1993; Edwards et al. 1996; volume 10 on line).

Currently considered valid: No

Haliplanella Hand, 1956

Type species: Sagartia Luciae Verrill, 1898, by original designation.

Nomenclature notes: Authorship is in agreement with Edwards and Hopwood (1966). Sagartia Lucia is also type species of Jancis Stephenson, 1935.

Spelling errors or variants: Haliphlanella, Haliplanela

Currently considered valid: No

Haloclava Verrill, 1899a

Type species: Actinia producta Stimpson, 1856b, by original designation.

Nomenclature notes: Type species is in agreement with Carlgren (1949). Authorship is in agreement with Neave (1939b) and with Carlgren (1949).

Currently considered valid: Yes

Harenactis Torrey, 1902

Type species: Harenactis attenuata Torrey, 1902, by monotypy.

Nomenclature notes: Authorship is in agreement with Neave (1939b) and with Carlgren (1949).

Currently considered valid: Yes

Helaria Stechow, 1921

Type species: Actinia bellis Wright, 1856, by replacement.

Nomenclature notes: Replacement name (ICZN Article 60.2) for the junior homonym Heliactis. Authorship is in agreement with Neave (1939b).

Currently considered valid: No

Heliactis Thompson, 1858

Type species: Actinia bellis Wright, 1856, by monotypy.

Nomenclature notes: According to Neave (1939b), junior homonym of bird genus Heliactis of Lesson, 1837 [not seen: “Compl. Buffon, 9, 154”]. Stechow (1921) created the replacement name (ICZN Article 60.2) Helaria for this genus.

Spelling errors or variants: Helliactis

Currently considered valid: Yes 
Helianthopsis Kwietniewski, 1898

Type species: Helianthopsis ritteri Kwietniewski, 1898, by monotypy.

Nomenclature notes: Authorship is in agreement with Neave (1939b).

Currently considered valid: No

Heteractis Milne Edwards and Haime, 1851

Type species: Actinia Aurora Quoy and Gaimard, 1833, by monotypy.

Nomenclature notes: Type species is in agreement with Carlgren (1949) and with Dunn (1981). In agreement with Neave (1939b), senior homonym of [1] bryozoan genus Heteractis of Gabb, W. M. and G. H. Horn, 1862, Monograph of the fossil Polyzoa of the secondary and tertiary formations of North America. Journal of the Academy of Natural Sciences of Philadelphia, series 2, 5:156; [2] hydrozoan genus Heteractis of Allman, G. J., 1864, On the construction and limitation of genera among the Hydroida. Annals and Magazine of Natural History, series 3, 13:359; and [3] echinoderm genus Heteractis of Lambert, J., 1897, Note sur quelques échinides éocènes de l'Aude. Bulletin de la Société Géologique de France, series 3, 25:509. Authorship of all genera is in agreement with Neave (1939); Carlgren (1949) erroneously gave 1857 as the date of the actiniarian genus.

Currently considered valid: Yes

Heteranthus Klunzinger, 1877

Type species: Heteranthus verruculatus Klunzinger, 1877, by monotypy.

Nomenclature notes: Type species is in agreement with Carlgren (1949) and with den Hartog (1980). Authorship is in agreement with Neave (1939b) and with Carlgren (1949).

Currently considered valid: Yes

Heterodactyla Hemprich and Ehrenberg in Ehrenberg, 1834

Type species: Heterodactyla Hemprichii Ehrenberg, 1834, by monotypy.

Nomenclature notes: Type species is in agreement with Carlgren (1949). Authorship is in agreement with Neave (1939b), but Carlgren (1949) erroneously gave 1851 as the date of publication.

Currently considered valid: Yes

Homactis Verrill, 1869b

Type species: Homactis rupicola Verrill, 1869b, by monotypy.

Nomenclature notes: Authorship is in agreement with Neave (1939b).

Currently considered valid: No

Homostichanthus Duerden, 1900

Type species: Actinia anemone Ellis, 1768, by monotypy.

Nomenclature notes: Neave (1939b) erroneously gave 1899 as the date of publication; Carlgren (1949) gave it correctly.

Spelling errors or variants: Homosticanthus

Currently considered valid: No

Hoplophoria Wilson, 1890

Type species: Hoplophoria coralligens Wilson, 1890, by monotypy.

Nomenclature notes: Authorship is in agreement with Neave (1939b).

Currently considered valid: No

Hormathia Gosse, 1859

Type species: Hormathia Margarita Gosse, 1859, by monotypy.

Nomenclature notes: Type species is not in agreement with Carlgren (1949). Authorship is in agreement with Neave (1939b) and with Carlgren (1949).

Spelling errors or variants: Homathia, Hormatia

Currently considered valid: Yes

Hormathianthus Carlgren, 1943

Type species: Hormathianthus tuberculatus Carlgren, 1943, by monotypy. 
Nomenclature notes: Authorship is in agreement Carlgren (1949) and with Neave (1950).

Currently considered valid: Yes

Hormosoma Stephenson, 1918a

Type species: Hormosoma scotti Stephenson, 1918a, by original designation.

Nomenclature notes: Authorship is in agreement with Neave (1939b) and with Carlgren (1949).

Currently considered valid: Yes

Iluanthos Forbes, 1840

Type species: Iluanthos Scoticus Forbes, 1840, by monotypy.

Nomenclature notes: Authorship is in agreement with Neave (1939b).

Spelling errors or variants: Ilyanthus

Currently considered valid: No

Ilyactis Andres, 1881

Type species: Ilyactis torquata Andres, 1881, by monotypy.

Nomenclature notes: Not listed in NZ (Neave 1939a, b, 1940a, b, 1950; Edwards \& Hopwood 1966; Edwards \& Vevers 1975; Edwards \& Tobias 1993; Edwards et al. 1996; volume 10 on line).

Currently considered valid: Yes

Ilyanthopsis Hertwig, 1888

Type species: Ilyanthopsis longifilis Hertwig, 1888, by monotypy.

Nomenclature notes: Authorship is in agreement with Neave (1939b).

Currently considered valid: No

Iosactis Riemann-Zürneck, 1997

Type species: Iosactis vagabunda Riemann-Zürneck, 1997, by monotypy.

Nomenclature notes: Authorship is in agreement with NZ 10 (on line).

Currently considered valid: Yes

Isacmaea Ehrenberg, 1834

Type species: None

Nomenclature notes: No type species has been designated for this genus; 12 species were included in it originally. Authorship is in agreement with Neave (1939b).

Spelling errors or variants: isacmaea

Currently considered valid: No

Isactinernus Carlgren, 1918

Type species: Isactinernus 4-lobatus Carlgren, 1918, by monotypy.

Nomenclature notes: Authorship is in agreement with Neave (1939b) and with Carlgren (1949).

Currently considered valid: Yes

Isactinia Carlgren, 1900a

Type species: Anemonia citrina Haddon and Shackleton, 1893, by subsequent designation.

Nomenclature notes: Type species was designated by Carlgren (1947) and is in agreement with Carlgren (1949). Authorship is in agreement with Neave (1939b) and with Carlgren (1949). Anemonia citrina is also type species of Telactinia England, 1987.

Currently considered valid: Yes

Isadamsia Carlgren, 1928a

Type species: Isadamsia cancrisocia Carlgren, 1928a, by monotypy.

Nomenclature notes: Authorship is in agreement with Neave (1939b) and with Carlgren (1949).

Currently considered valid: No 
Isanemonia Carlgren, 1950b

Type species: Isanemonia australis Carlgren, 1950b, by monotypy.

Nomenclature notes: Not listed in NZ (Neave 1939a, b, 1940a, b, 1950; Edwards \& Hopwood 1966; Edwards \& Vevers 1975; Edwards \& Tobias 1993; Edwards et al. 1996; volume 10 on line).

Currently considered valid: Yes

Isantheopsis Carlgren, 1942

Type species: Actinopsis rosea Studer, 1879, by monotypy.

Nomenclature notes: Not listed in NZ (Neave 1939a, b, 1940a, b, 1950; Edwards \& Hopwood 1966; Edwards \& Vevers 1975; Edwards \& Tobias 1993; Edwards et al. 1996; volume 10 on line).

Currently considered valid: Yes

Isanthus Carlgren, 1938

Type species: Isanthus capensis Carlgren, 1938, by monotypy.

Nomenclature notes: Authorship is in agreement with Neave (1950) and with Carlgren (1949).

Currently considered valid: Yes

Isoaulactinia Belém, Herrera Moreno, and Schlenz, 1996

Type species: Aulactinia stelloides McMurrich, 1889a, by original designation.

Nomenclature notes: Not listed in NZ (Neave 1939a, b, 1940a, b, 1950; Edwards \& Hopwood 1966; Edwards \& Vevers 1975; Edwards \& Tobias 1993; Edwards et al. 1996; volume 10 on line).

Currently considered valid: Yes

Isocradactis Carlgren, 1924a

Type species: Cradactis magna Stuckey, 1909, by monotypy.

Nomenclature notes: Authorship is in agreement with Neave (1939b) and with Carlgren (1949).

Currently considered valid: No

Isoedwardsia Carlgren, 1900a

Type species: Isoedwardsia ingolfi Carlgren, 1921, by subsequent designation.

Nomenclature notes: Type species was designated by Carlgren (1921) and is in agreement with Carlgren (1949). Authorship is in agreement with Neave (1939b) and with Carlgren (1949).

Currently considered valid: Yes

Isometridium Carlgren, 1951

Type species: Isometridium rickettsi Carlgren, 1951, by monotypy.

Nomenclature notes: Edwards and Hopwood (1966) stated the genus was described by Carlgren in 1949. The name Isometridium as published by Carlgren in 1949, is a nomen nudum: it is unavailable under ICZN Article 13.3.1 because the single included species, Isometridium Richettsi, is a nomen nudum, being unavailable under ICZN Article 13.1.1.

Currently considered valid: No

Isoparactis Stephenson, 1920

Type species: Paractis ferax Stuckey, 1909, by monotypy.

Nomenclature notes: Authorship is in agreement with Neave (1939b) and with Carlgren (1949).

Currently considered valid: No

Isophellia Carlgren, 1900a

Type species: Isophellia sabulosa Carlgren, 1900a, by original designation.

Nomenclature notes: Type species is in agreement with Carlgren (1949). Authorship is in agreement with Neave (1939b) and with Carlgren (1949).

Currently considered valid: Yes

Isosicyonis Carlgren, 1927

Type species: Paractis alba Studer, 1879, by monotypy. 
Nomenclature notes: Authorship is in agreement with Neave (1939b) and with Carlgren (1949).

Currently considered valid: Yes

Isotealia Carlgren, 1899b

Type species: Isotealia antarctica Carlgren, 1899b, by monotypy.

Nomenclature notes: Type species is in agreement with Carlgren (1949). Neave (1939a) gave the date as 1898; there is evidence that publication was in 1899, the date given by Carlgren (1949).

Currently considered valid: Yes

Isoulactis Carlgren, 1959

Type species: Isoulactis chilensis Carlgren, 1959, by monotypy.

Nomenclature notes: Authorship is in agreement with Edwards and Vevers (1975).

Currently considered valid: Yes

Ixalactis Haddon, 1898

Type species: Phymanthus simplex Haddon and Shackleton, 1893, by monotypy.

Nomenclature notes: Authorship is in agreement with Neave (1939b).

Currently considered valid: No

Jancis Stephenson, 1935

Type species: Sagartia Luciae Verrill, 1898, by monotypy.

Nomenclature notes: Authorship is in agreement with Neave (1939b). This name was proposed conditionally; according to the ICZN, having been published prior to 1960, it "may be available" (Article 15.1). We regard it as available, being listed in NZ (Neave 1939b) and mentioned by Carlgren (1949). Sagartia Lucia is also type species of Haliplanella Hand, 1956.

Currently considered valid: No

Kadosactis Danielssen, 1890

Type species: Kadosactis rosea Danielssen, 1890, by monotypy.

Nomenclature notes: Type species is in agreement with Carlgren (1949). Authorship is in agreement with Neave (1939b) and with Carlgren (1949).

Currently considered valid: Yes

Kadosanthus Carlgren, 1934a

Type species: Kadosactis sulcata Carlgren, 1934a, by monotypy.

Nomenclature notes: Not listed in NZ (Neave 1939a, b, 1940a, b, 1950; Edwards \& Hopwood 1966; Edwards \& Vevers 1975; Edwards \& Tobias 1993; Edwards et al. 1996; volume 10 on line).

Currently considered valid: No

Kalliphobe Busch, 1851

Type species: Kalliphobe appendiculata Busch, 1851, by monotypy.

Nomenclature notes: Neave (1939b) regarded "Kalliphobe Metschnikoff [non Busch] 1871" and "Kalliphobe Busch 1851 " as homonyms; Andres (1883, page 360), who rendered the name "Calliphobe," regarded them as synonyms. Determining whether they refer to a single genus is unlikely to be possible because both accounts are of larvae; thus Andres' position seems prudent.

Spelling errors or variants: Calliphobe

Currently considered valid: No

Korenia Danielssen, 1890

Type species: Korenia margaritacea Danielssen, 1890, by monotypy.

Nomenclature notes: In agreement with Neave (1939b), junior homonym of gastropod genus Korenia of Friele, H., 1877 , Tungebev æbningen hos de norske Rhipidoglossa. Archiv for Mathematik og Naturvidenskab 2:205. Authorship of both genera is in agreement with Neave (1939b).

Currently considered valid: No 
Korsaranthus Riemann-Zürneck and Griffiths, 1999

Type species: Condylactis natalensis Carlgren, 1938, by original designation.

Nomenclature notes: Authorship is in agreement with NZ 10 (on line).

Currently considered valid: Yes

Kyathactis Danielssen, 1890

Type species: Kyathactis hyalina Danielssen, 1890, by monotypy.

Nomenclature notes: Not listed in NZ (Neave 1939a, b, 1940a, b, 1950; Edwards \& Hopwood 1966; Edwards \& Vevers 1975; Edwards \& Tobias 1993; Edwards et al. 1996; volume 10 on line).

Currently considered valid: No

Kylindrosactis Danielssen, 1890

Type species: Kylindrosactis elegans Danielssen, 1890, by monotypy.

Nomenclature notes: Authorship is in agreement with Neave (1939b).

Currently considered valid: No

Lebrunia Duchassaing de Fonbressin and Michelotti, 1860

Type species: Lebrunia neglecta Duchassaing de Fonbressin and Michelotti, 1860, by monotypy.

Nomenclature notes: Type species is not in agreement with Carlgren (1949). Authorship is in agreement with Neave (1939b) and with Carlgren (1949).

Spelling errors or variants: Labrunia, Lebrunea, Lubrunia

Currently considered valid: Yes

Lecythia Sars, 1829

Type species: Lecythia brevicornis Sars, 1829, by monotypy.

Nomenclature notes: Type species is in agreement with Williams (1981), who regarded this genus a nomen dubium. In agreement with Neave (1939b), senior homonym of protozoan Lecythia of Wright, T. S., 1861, Observations on British Protozoa and zoophytes. Annals and Magazine of Natural History, series 3, 8(43):123. Authorship of both genera is in agreement with Neave (1939b).

Currently considered valid: No

Leiotealia Hertwig, 1882

Type species: Actinia nymphae Drayton in Dana, 1846, by monotypy.

Nomenclature notes: Genus name erroneously listed in Neave (1939b) as Leiotaelia.

Spelling errors or variants: Leiotaelia

Currently considered valid: Yes

Leipsiceras Stephenson, 1918 b

Type species: Bolocera pollens McMurrich, 1898, by monotypy.

Nomenclature notes: Type species is in agreement with Carlgren (1949); not listed in NZ (Neave 1939a, b, 1940a, b, 1950; Edwards \& Hopwood 1966; Edwards \& Vevers 1975; Edwards \& Tobias 1993; Edwards et al. 1996 ; volume 10 on line). Authorship is in agreement with Carlgren (1949).

Currently considered valid: Yes

Lepactis Andres, 1883

Type species: Actinia squamosa Bruguiere, 1789, by monotypy.

Nomenclature notes: Not listed in NZ (Neave 1939a, b, 1940a, b, 1950; Edwards \& Hopwood 1966; Edwards \& Vevers 1975; Edwards \& Tobias 1993; Edwards et al. 1996; volume 10 on line).

Currently considered valid: Yes

Leptoteichus Stephenson, 1918a

Type species: Leptoteichus insignis Stephenson, 1918a, by original designation.

Nomenclature notes: Authorship is in agreement with Neave (1939b).

Currently considered valid: No 
Lilliella Stephenson, 1918a

Type species: Lilliella lacunifera Stephenson, 1918a, by original designation.

Nomenclature notes: Authorship is in agreement with Neave (1939b).

Currently considered valid: No

Limnactinia Carlgren, 1921

Type species: Limnactinia laevis Carlgren, 1921, by monotypy.

Nomenclature notes: Type species is in agreement with Carlgren (1949). Neave (1939b) erroneously stated Limnactinia was described in 1922; Carlgren (1949) gave it correctly.

Currently considered valid: Yes

Liponema Hertwig, 1888

Type species: Liponema multiporum Hertwig, 1882, by monotypy.

Nomenclature notes: Type species is in agreement with Carlgren (1949). Authorship is in agreement with Neave (1940b); Carlgren (1949) erroneously gave 1882 as the date of publication.

Currently considered valid: Yes

Litophellia Carlgren, 1938

Type species: Litophellia octoradiata Carlgren, 1938, by monotypy.

Nomenclature notes: Authorship is in agreement with Carlgren (1949) and with Neave (1950).

Currently considered valid: No

Lophactis Verrill, 1869a

Type species: Lophactis ornata Verrill, 1869a, by monotypy.

Nomenclature notes: Authorship is in agreement with Neave (1939b).

Currently considered valid: No

Macranthea Verrill, 1928

Type species: Macranthea cookei Verrill, 1928, by monotypy.

Nomenclature notes: Authorship is in agreement with Neave (1940a).

Currently considered valid: No

Macrocnema Carlgren, 1928a

Type species: Macrocnema nicobarica Carlgren, 1928a, by monotypy.

Nomenclature notes: In agreement with Neave (1940a), junior homonym of Macrocnema of Stephens, J. F., 1831, Illustrations of British Entomology; or, A Synopsis of Indigenous Insects, volume 4, page 317. Authorship of both genera is in agreement with Neave (1940a); that of the actiniarian genus is in agreement with Carlgren (1949).

Currently considered valid: Yes

Macrodactyla Haddon, 1898

Type species: Condylactis aspera Haddon and Shackleton, 1893, by monotypy.

Nomenclature notes: Type species is in agreement with Dunn (1981). According to Neave (1940a), junior homonym of Macrodactyla of Harris in Hitchcock, E., 1833 [not seen: “Rep. Geol. Min. Zool. Massach., 575”]. Authorship of the actiniarian genus is in agreement with Neave (1940a) and with Carlgren (1949).

Currently considered valid: Yes

Madoniactis Danielssen, 1890

Type species: Madoniactis lofotensis Danielssen, 1890, by monotypy.

Nomenclature notes: Authorship is in agreement with Neave (1940a).

Currently considered valid: No

Maractis Fautin and Barber, 1999

Type species: Maractis rimicarivora Fautin and Barber, 1999, by original designation. 
Nomenclature notes: Authorship is in agreement with NZ 10 (on line).

Currently considered valid: Yes

Marianactis Fautin and Hessler, 1989

Type species: Marianactis bythios Fautin and Hessler, 1989, by original designation.

Nomenclature notes: Authorship is in agreement with Edwards et al. (1996).

Currently considered valid: Yes

Marsupifer Carlgren, 1901

Type species: Marsupifer Valdiviae Carlgren, 1901, by monotypy.

Nomenclature notes: Authorship is in agreement with Neave (1940a).

Currently considered valid: No

Megalactis Hemprich and Ehrenberg in Ehrenberg, 1834

Type species: Megalactis Hemprichii Ehrenberg, 1834, by monotypy.

Nomenclature notes: Type species is in agreement with Carlgren (1949). Authorship is in agreement with Neave (1940a) and with Carlgren (1949).

Currently considered valid: Yes

Melactis Milne Edwards, 1857

Type species: None

Nomenclature notes: No type species has been designated for this genus; two species were included in it originally. Authorship is in agreement with Neave (1940a).

Currently considered valid: No

Mena Stephenson, 1920

Type species: Phytocoetes chilkaeus Annandale, 1915, by monotypy.

Nomenclature notes: Type species is in agreement with Carlgren (1949). According to Eschmeyer, W., 1998, Catalog of Fishes, vol. 3, fish genus Mena of Swainson, W., 1839, On the Natural History of Fishes, Amphibians, \& Reptiles or Monocardian Animals, volume 2, page 215, is an incorrect subsequent spelling of genus Maena Cuvier, 1829; Swainson's genus, which is not in prevailing usage, is not available and so does not enter into homonymy (ICZN Article 33.3). Authorship of the actiniarian genus is in agreement with Carlgren (1949); that of both genera is in agreement with Neave (1940a).

Currently considered valid: Yes

Mesacmaea Andres, 1883

Type species: Ilyanthus stellatus Andres, 1881, by monotypy.

Nomenclature notes: Authorship is in agreement with Neave (1940a) and with Carlgren (1949). Ehrenberg (1834) also proposed a genus Mesacmaea, which is a nomen nudum: an available species name was not assigned in combination with this genus name (ICZN Article 12.2.5).

Spelling errors or variants: Mesacmaea

Currently considered valid: Yes

Mesactinia England, 1987

Type species: Mesactinia ganensis England, 1987, by original designation.

Nomenclature notes: Not listed in NZ (Edwards et al. 1996; volume 10 on line).

Currently considered valid: Yes

Metactis Milne Edwards and Haime, 1851

Type species: Actinia Vas Quoy and Gaimard, 1833, by monotypy.

Nomenclature notes: Type species is in agreement with Carlgren (1949). Authorship is in agreement with Neave (1940a).

Currently considered valid: No 
Metapeachia Carlgren, 1943

Type species: Peachia tropica Panikkar, 1938, by monotypy.

Nomenclature notes: Authorship is in agreement with Neave (1950) and with Carlgren (1949).

Currently considered valid: Yes

Metedwardsia Carlgren, 1947

Type species: Milne-edwardsia akkeshi Uchida, 1932b, by monotypy.

Nomenclature notes: Authorship is in agreement with Edwards and Hopwood (1966) and with Carlgren (1949).

Currently considered valid: Yes

Metridium de Blainville, 1824

Type species: Actinia dianthus Ellis, 1768, by monotypy.

Nomenclature notes: Oken (1815) was rejected for nomenclatorial purposes in Opinion 417 of the International Commission on Zoological Nomenclature (Bulletin of Zoological Nomenclature 14:1-42; September 1956) because the author did not apply the principles of binominal nomenclature. de Blainville (1824) made the genus name Metridium available, in agreement with Opinion 1269 of the International Commission of Zoological Nomenclature (Bulletin of Zoological Nomenclature 41:19-21; March 1984). Type species and authorship are not in agreement with Carlgren (1949).

Spelling errors or variants: Methridium

Currently considered valid: Yes

Milneedwardsia Carlgren, 1892

Type species: Milne-Edwardsia Loveni Carlgren, 1892

Nomenclature notes: In agreement with Neave (1940a), junior homonym of mollusc genus Milne-Edwardsia of Bourguignat, J. R., 1877, Histoire des clausilies de France vivantes et fossiles. Annales des Sciences Naturelles, Zoologie 6(2):59. Authorship of both genera is in agreement with Neave (1940a).

Spelling errors or variants: Milne-Edwardsia

Currently considered valid: No

Mimetridium Hand, 1961

Type species: Mimetridium cryptum Hand, 1961, by monotypy.

Nomenclature notes: Authorship is in agreement Edwards and Vevers (1975).

Currently considered valid: Yes

Minyas Cuvier, 1817

Type species: Mynias cyanea Cuvier, 1817, by monotypy.

Nomenclature notes: Type species is not in agreement with Carlgren (1949). In agreement with Neave (1940a), junior homonym of lepidopteran genus Minyas of Savigny, J. C., 1816, Mémoires sur les Animaux sans Vértebres, part 1, page 31. Cuvier (1817), who described the actiniarian in phylum Echinodermata, spelled the genus name both Minyas and Mynias; the spelling Minyas was fixed by de Blainville (1830), acting as First Reviser (ICZN Article 24.2.1). de Blainville (1830) also moved the genus to phylum Coelenterata, and resolved the homonymy by creating Actinecta as a replacement name (ICZN Article 60.2). Authorship of both genera is in agreement with Neave (1940a); Carlgren (1949) erroneously gave 1827 as the date.

Spelling errors or variants: Mynias

Currently considered valid: Yes

Mitactis Haddon and Duerden, 1896

Type species: None

Nomenclature notes: No type species has been designated for this genus; two species were included in it originally. Neave (1940a) erroneously gave 1898 as the date of publication.

Currently considered valid: No

Monactis Riemann-Zürneck, 1986

Type species: Paractis vestita Gravier, 1918, by original designation. 
Nomenclature notes: Authorship is in agreement with Edwards et al. (1996).

Currently considered valid: Yes

Moschata Renier in de Blainville, 1830

Type species: Moschata rhododactyla de Blainville, 1830, by monotypy.

Nomenclature notes: Authorship is in agreement with Neave (1940a).

Currently considered valid: No

Myonanthus McMurrich, 1893

Type species: Myonanthus ambiguus McMurrich, 1893, by monotypy.

Nomenclature notes: Type species is in agreement with Carlgren (1949). Neave (1940a) erroneously gave 1895 as the date of publication; Carlgren (1949) gave it correctly.

Currently considered valid: Yes

Myriactis Haddon, 1888

Type species: Myriactis tubicola Haddon, 1888, by monotypy.

Nomenclature notes: Authorship is in agreement with Neave (1940a).

Currently considered valid: Yes

Nautactis Milne Edwards, 1857

Type species: Actinia olivacea Le Sueur, 1817, by monotypy.

Nomenclature notes: Neave (1940a) erroneously attributed authorship to Milne-Edwards \& Haime.

Currently considered valid: Yes

Nectothela Verrill, 1928

Type species: Nectothela lilae Verrill, 1928, by monotypy.

Nomenclature notes: Authorship is in agreement with Neave (1940s).

Currently considered valid: No

Nemactis Milne Edwards, 1857

Type species: None

Nomenclature notes: No type species has been designated for this genus; three species were included in it originally. Authorship is in agreement with Neave (1940a).

Currently considered valid: Yes

Nemanthus Carlgren, 1940

Type species: Sagartia nitida Wassilieff, 1908, by original designation.

Nomenclature notes: Type species is in agreement with Carlgren (1949). Authorship is in agreement with Carlgren (1949) and with Neave (1950).

Spelling errors or variants: Namanthus

Currently considered valid: Yes

Nematostella Stephenson, 1935

Type species: Nematostella vectensis Stephenson, 1935, by original designation.

Nomenclature notes: Type species is in agreement with Carlgren (1949). Authorship is in agreement with Neave (1940a) and with Carlgren (1949).

Currently considered valid: Yes

Neoaiptasia Parulekar, 1969

Type species: Neoaiptasia commensali Parulekar, 1969, by original designation.

Nomenclature notes: Authorship is in agreement with Edwards and Tobias (1993).

Currently considered valid: Yes 
Neocondylactis England, 1987

Type species: Neocondylactis singaporensis England, 1987, by original designation.

Nomenclature notes: Not listed in NZ (Edwards et al. 1996; volume 10 on line).

Currently considered valid: Yes

Neohalcampa Sanamyan, 2001

Type species: Neohalcampa sheikoi Sanamyan, 2001, by original designation.

Nomenclature notes: Authorship is in agreement with NZ 10 (on line).

Currently considered valid: Yes

Neoparacondylactis Zamponi, 1974

Type species: Neoparacondylactis haraldoi Zamponi, 1974, by original designation.

Nomenclature notes: Authorship is in agreement with Edwards and Tobias (1993).

Currently considered valid: Yes

Neophellia Uchida, 1938

Type species: Neophellia mutsuensis Uchida, 1938, by monotypy.

Nomenclature notes: Authorship is in agreement with Neave (1950); Carlgren (1949) erroneously gave 1939 as the date.

Currently considered valid: No

Nevadne Stephenson, 1922

Type species: Gyrostoma glaucum Annandale, 1915, by monotypy.

Nomenclature notes: Authorship is in agreement with Neave (1940a) and with Carlgren (1949).

Currently considered valid: Yes

Oceanactis Moseley, 1877

Type species: Oceanactis rhodactylus Moseley, 1877, by monotypy.

Nomenclature notes: Authorship is in agreement with Neave (1940a).

Currently considered valid: Yes

Octineon Moseley in Fowler, 1894

Type species: Ammodiscus Lindahli Carpenter and Jeffreys, 1871, by replacement.

Nomenclature notes: Carlgren (1949) erroneously gave the type species as Carpenter in Fowler, 1894. Replacement name (ICZN Article 60.2) for the junior homonym Ammodiscus. Neave (1940a) gave authorship as Fowler, but Fowler attributed it to Moseley, as Carlgren (1949) gave it.

Currently considered valid: Yes

Octophellia Andres, 1883

Type species: None

Nomenclature notes: No type species has been designated for this genus; two species were included in it originally. Authorship is in agreement with Neave (1940a).

Currently considered valid: Yes

Onubactis López-González, den Hartog, and García-Gómez, 1995

Type species: Onubactis rocioi López-González, den Hartog, and García-Gómez, 1995, by original designation.

Nomenclature notes: Authorship is in agreement with NZ 10 (on line).

Currently considered valid: Yes

Ophiodiscus Hertwig, 1882

Type species: Ophiodiscus annulatus Hertwig, 1882, by monotypy.

Nomenclature notes: Type species is in agreement with Carlgren (1949). Authorship is in agreement with Carlgren (1949) and with Neave (1940a), who stated that Stephanactis was described by Hertwig (1882), which is true; however, it appears that the German version of Hertwig's publication on the Challenger anemones appeared before that in the expedition series, which Neave cited. 
Currently considered valid: Yes

Oractis McMurrich, 1893

Type species: Oractis Diomedea McMurrich, 1893, by monotypy.

Nomenclature notes: Neave (1940a) erroneously gave the date as 1895; Carlgren (1949) gave it correctly.

Currently considered valid: Yes

Oulactis Milne Edwards and Haime, 1851

Type species: Metridium muscosum Drayton in Dana, 1846, by monotypy.

Nomenclature notes: Type species is in agreement with Carlgren (1949). Authorship is in agreement with Neave (1940a) and with Carlgren (1949).

Currently considered valid: Yes

Pacmanactis López-González, Rodríguez, and Segonzac, 2005

Type species: Pacmanactis hashimotoi López-González, Rodríguez, and Segonzac, 2005, by original designation.

Nomenclature notes: Not listed in NZ (Neave 1939a, b, 1940a, b, 1950; Edwards \& Hopwood 1966; Edwards \& Vevers 1975; Edwards \& Tobias 1993; Edwards et al. 1996; volume 10 on line).

Currently considered valid: No

Parabunodactis Carlgren, 1928a

Type species: Bunodactis inflexibilis Carlgren, 1928a, by monotypy.

Nomenclature notes: Not listed in NZ (Neave 1939a, b, 1940a, b, 1950; Edwards \& Hopwood 1966; Edwards \& Vevers 1975; Edwards \& Tobias 1993; Edwards et al. 1996; volume 10 on line). Authorship is in agreement with Carlgren (1949).

Currently considered valid: Yes

Paracalliactis Carlgren, 1928a

Type species: Paracalliactis valdiviae Carlgren, 1928a, by monotypy.

Nomenclature notes: Type species is in agreement with Carlgren (1949). Authorship is in agreement with Neave (1940a) and with Carlgren (1949).

Currently considered valid: Yes

Paracondylactis Carlgren, 1934c

Type species: Condylactis hertwigi Wassilieff, 1908, by subsequent designation.

Nomenclature notes: Type species was designated by Carlgren (1949). Authorship is in agreement with Neave (1940b) and with Carlgren (1949).

Currently considered valid: Yes

Paractinia Andres, 1883

Type species: Actinia striata Risso, 1826, by monotypy.

Nomenclature notes: Authorship is in agreement with Neave (1940a).

Currently considered valid: Yes

Paractinostola Carlgren, 1928a

Type species: Paractinostola bulbosa Carlgren, 1928a, by subsequent designation.

Nomenclature notes: Type species was designated by Carlgren (1949). Authorship is in agreement with Neave (1940a) and with Carlgren (1949).

Currently considered valid: Yes

Paractis Milne Edwards and Haime, 1851

Type species: Actinia impatiens Couthouy in Dana, 1846, by monotypy.

Nomenclature notes: Authorship is in agreement with Neave (1940a).

Spelling errors or variants: Paracis, Paratis, Peractis

Currently considered valid: Yes 
Paraedwardsia Carlgren in Nordgaard, 1905

Type species: Paraedwardsia arenarea Carlgren in Nordgaard, 1905, by monotypy.

Nomenclature notes: Type species is in agreement with Carlgren (1949). Neave (1940a) attributed authorship to Joergensen (1905) from a manuscript by Carlgren; Carlgren (1949) attributed authorship simply to Carlgren.

Currently considered valid: Yes

Parahalcampa Carlgren, 1927

Type species: Parahalcampa antarctica Carlgren, 1927, by original designation.

Nomenclature notes: Neave (1940b) stated the genus was described by Carlgren in 1921. The name Parahalcampa as published by Carlgren in 1921, is a nomen nudum: it is unavailable under ICZN Article 13.3.1 because the single included species, Parahalcampa antarctica, is a nomen nudum, being unavailable under ICZN Article 13.1.1.

Currently considered valid: Yes

Paraiptasia England, 1992

Type species: Actinia radiata Stimpson, 1856a, by original designation.

Nomenclature notes: Authorship is in agreement with Edwards et al. (1996).

Currently considered valid: Yes

Paraisanthus Sanamyan and Sanamyan, 1998

Type species: Paraisanthus tamarae Sanamyan and Sanamyan, 1998, by monotypy.

Nomenclature notes: Authorship is in agreement with NZ 10 (on line).

Currently considered valid: Yes

Paraisometridium Zamponi, 1978b

Type species: Paraisometridium pehuensis Zamponi, 1978b, by monotypy.

Nomenclature notes: Authorship is in agreement with Edwards et al. (1996).

Currently considered valid: Yes

Paranemonia Carlgren, 1900a

Type species: Anemonia cinerea Contarini, 1844, by monotypy.

Nomenclature notes: Not listed in NZ (Neave 1939a, b, 1940a, b, 1950; Edwards \& Hopwood 1966; Edwards \& Vevers 1975; Edwards \& Tobias 1993; Edwards et al. 1996; volume 10 on line). Authorship is in agreement with Carlgren (1949).

Currently considered valid: Yes

Paranthea Verrill, 1868

Type species: Dysactis pallida L. Agassiz in Verrill, 1864b, by original designation.

Nomenclature notes: Authorship is in agreement with Neave (1940a).

Currently considered valid: No

Parantheoides Carlgren, 1899b

Type species: Parantheoides crassa Carlgren, 1899b, by monotypy.

Nomenclature notes: Neave (1940a) erroneously gave 1898 as the date of publication.

Currently considered valid: No

Parantheopsis McMurrich, 1904

Type species: Actinia cruentata Couthouy in Dana, 1846, by monotypy.

Nomenclature notes: Type species is in agreement with Carlgren (1949), who erroneously gave 1849 as the date of publication. Authorship is in agreement with Neave (1940a) and with Carlgren (1949).

Currently considered valid: Yes

Paranthosactis López-González, Rodríguez, Gili, and Segonzac, 2003

Type species: Paranthosactis denhartogi López-González, Rodríguez, Gili, and Segonzac, 2003, by original designation. Nomenclature notes: Authorship is in agreement with NZ 10 (on line). 
Paranthus Andres, 1883

Type species: Entacmaea chromatodera Schmarda, 1852, by monotypy.

Nomenclature notes: Type species is in agreement with Carlgren (1949). Authorship is in agreement with Neave (1940a) and with Carlgren (1949).

Currently considered valid: Yes

Paraphellia Haddon, 1889

Type species: Chitonactis expansa Haddon, 1886, by monotypy.

Nomenclature notes: In agreement with Neave (1940a), junior homonym of actiniarian Paraphellia of Verrill (1868). Type species is in agreement with Carlgren (1949). Authorship of both genera is in agreement with Neave (1940a); that of the actiniarian genus is in agreement with Carlgren (1949).

Currently considered valid: Yes

Paraphellia Verrill, 1868

Type species: Phellia inequalis Verrill, 1868, by monotypy.

Nomenclature notes: In agreement with Neave (1940a), senior homonym of actiniarian Paraphellia of Haddon (1889). Authorship of both genera is in agreement with Neave (1940a).

Currently considered valid: Yes

Paraphelliactis Carlgren, 1928b

Type species: Paraphelliactis spinosa Carlgren, 1928b, by monotypy.

Nomenclature notes: Type species is in agreement with Carlgren (1949). Authorship is in agreement with Neave (1940) and with Carlgren (1949).

Currently considered valid: Yes

Parasicyonis Carlgren, 1921

Type species: Parasicyonis sarsii Carlgren, 1921, by original designation.

Nomenclature notes: Type species is in agreement with Carlgren (1949). Authorship is in agreement with Neave (1940a) and with Carlgren (1949).

Spelling errors or variants: Paracicyonis

Currently considered valid: Yes

Parastephanauge Dufaure, 1959

Type species: Parastephanauge Paxi Dufaure, 1959, by monotypy.

Nomenclature notes: Authorship is in agreement with Edwards and Vevers (1975).

Currently considered valid: Yes

Paratealia Mathew and Kurian, 1979

Type species: Paratealia keralensis Mathew and Kurian, 1979, by monotypy.

Nomenclature notes: Authorship is in agreement with Edwards et al. (1996).

Currently considered valid: Yes

Parathoe Carlgren, 1928a

Type species: Cereus Stimpsonii Verrill, 1869b, by monotypy.

Nomenclature notes: In agreement with Neave (1940a), junior homonym of Parathoe of Miers, J. E., 1879, Descriptions of new or little-known species of maioid Crustacea (Oxyrhyncha) in the collection of the British Museum. Annals and Magazine of Natural History Series 5, 4:16. Carlgren (1938) created Anthothoe as a replacement name. Authorship of both genera is in agreement with Neave (1940a).

Currently considered valid: No

Peachia Gosse, 1855

Type species: Peachia hastata Gosse, 1855, by subsequent designation. 
Nomenclature notes: Type species was designated by Carlgren (1949). Authorship is in agreement with Neave (1940a) and with Carlgren (1949).

Spelling errors or variants: Peachya

Currently considered valid: Yes

Pelocoetes Annandale, 1915

Type species: Metridium schillerianum exul Annandale, 1907, by monotypy.

Nomenclature notes: Carlgren (1949) erroneously gave the type species as Pelocoetes exul, dated from 1915. Authorship is in agreement with Neave (1940) and with Carlgren (1949).

Spelling errors or variants: Pelocotes

Currently considered valid: Yes

Pentactinia Carlgren, 1900b

Type species: Pentactinia californica Carlgren, 1900b, by monotypy.

Nomenclature notes: Neave (1940a) erroneously gave authorship of the genus as 1901, although he gave correct authorship of the publication. Authorship is in agreement with Carlgren (1949).

Currently considered valid: Yes

Peronanthus Hiles, 1899

Type species: Peronanthus verrucellae Hiles, 1899, by monotypy.

Nomenclature notes: Authorship is in agreement with Neave (1940a).

Currently considered valid: Yes

Petalactis Andres, 1883

Type species: None

Nomenclature notes: No type species has been designated for this genus; two species were included in it originally. Not listed in NZ (Neave 1939a, b, 1940a, b, 1950; Edwards \& Hopwood 1966; Edwards \& Vevers 1975; Edwards \& Tobias 1993; Edwards et al. 1996; volume 10 on line).

Currently considered valid: Yes

Phellia Gosse, 1858a

Type species: Phellia gausapata Gosse, 1858a, by subsequent designation.

Nomenclature notes: Type species was designated by Stephenson (1929), and is in agreement with Carlgren (1949). Authorship is in agreement with Neave (1940a) and with Carlgren (1949).

Currently considered valid: Yes

Phelliactis Simon, 1892

Type species: Phelliactis Hertwigii Simon, 1892, by monotypy.

Nomenclature notes: Type species is in agreement with Carlgren (1949). Authorship is in agreement with Neave (1940b) and with Carlgren (1949).

Currently considered valid: Yes

Phelliogeton Carlgren, 1927

Type species: Phelliogeton falklandicus Carlgren, 1927, by monotypy.

Nomenclature notes: Type species is in agreement with Carlgren (1949). Authorship is in agreement with Neave (1940a) and with Carlgren (1949).

Currently considered valid: Yes

Phelliomorpha Carlgren, 1902

Type species: Phellia crassa Danielssen, 1890, by monotypy.

Nomenclature notes: Authorship is in agreement with Neave (1940a).

Currently considered valid: No 
Phelliopsis Fischer, 1887

Type species: Phellia nummus Andres, 1881, by monotypy.

Nomenclature notes: Senior homonym of actiniarian genus Phelliopsis of Verrill, 1899c, in agreement with Neave (1940a, 1950). Authorship of both genera is in agreement with Neave (1940a, 1950).

Currently considered valid: No

Phelliopsis Verrill, 1899c

Type species: Phellia Panamensis Verrill, 1869a, by original designation.

Nomenclature notes: Junior homonym of actiniarian genus Phelliopsis of Fischer, 1887. Delphy (1939) resolved the homonymy by creating the replacement name (ICZN Article 60.2) Plastaphellia in agreement with Neave (1940a, 1950). Authorship of both genera is in agreement with Neave (1940a, 1950).

Currently considered valid: No

Phialoba Carlgren, 1951

Type species: Phialoba steinbecki Carlgren, 1951, by monotypy.

Nomenclature notes: Edwards and Hopwood (1966) stated the genus was described by Carlgren in 1949. The name Phialoba as published by Carlgren in 1949, is a nomen nudum: it is unavailable under ICZN Article 13.3.1 because the single included species, Phialoba steinbecki, is a nomen nudum, being unavailable under ICZN Article 13.1.1.

Currently considered valid: Yes

Philomedusa Müller, 1860

Type species: Philomedusa Vogtii Müller, 1860, by monotypy.

Nomenclature notes: Authorship is in agreement with Neave (1940a).

Currently considered valid: Yes

Phlyctaenominyas Andres, 1883

Type species: None

Nomenclature notes: No type species has been designated for this genus; two species were included in it originally. Erroneously rendered by Neave (1940a) as Phyctaenominyas.

Currently considered valid: No

Phlyctenactis Stuckey, 1909

Type species: Actinia tuberculosa Quoy and Gaimard, 1833, by subsequent designation.

Nomenclature notes: Type species was designated by Carlgren (1949). Authorship is in agreement with Neave (1940a) and with Carlgren (1949).

Currently considered valid: Yes

Phlyctenanthus Carlgren, 1950c

Type species: Phlyctenanthus australis Carlgren, 1950c, by monotypy.

Nomenclature notes: Edwards and Hopwood (1966) stated the genus was described by Carlgren in 1949. The name Phlyctenanthus as published by Carlgren in 1949, is a nomen nudum: it is unavailable under ICZN Article 13.3.1 because the single included species, Phlyctenanthus australis, is a nomen nudum, being unavailable under ICZN Article 13.1.1.

Currently considered valid: Yes

Phyllactis Milne Edwards and Haime, 1851

Type species: Metridium pratextum Couthouy in Dana, 1846, by monotypy.

Nomenclature notes: Type species is in agreement with Carlgren (1949). Authorship is in agreement with Neave (1940) and with Carlgren (1949).

Spelling errors or variants: Phylactis

Currently considered valid: Yes

Phyllodiscus Kwietniewski, 1897

Type species: Phyllodiscus Semoni Kwietniewski, 1897, by monotypy.

Nomenclature notes: Description of the actiniarian repeated (in nearly the same words) by Kwietniewski (1898). Author- 
ship is in agreement with Neave (1940a); Carlgren (1949) erroneously gave 1898 as the date.

Spelling errors or variants: Phillodiscus

Currently considered valid: Yes

Phyllominyas Andres, 1883

Type species: None

Nomenclature notes: No type species has been designated for this genus; two species were included in it originally. Authorship is in agreement with Neave (1940a).

Currently considered valid: No

Phymactis Milne Edwards, 1857

Type species: Actinia clematis Drayton in Dana, 1846, by subsequent designation.

Nomenclature notes: Type species was designated by Carlgren (1949), who erroneously gave 1849 as the date. Authorship is in agreement with Neave (1940a) and with Carlgren (1949).

Currently considered valid: Yes

Phymanthea Carlgren, 1959

Type species: Actinia pluvia Drayton in Dana, 1846, by monotypy.

Nomenclature notes: Authorship is in agreement with Edwards and Vevers (1975).

Spelling errors or variants: Phymantea

Currently considered valid: Yes

Phymanthus Milne Edwards and Haime, 1851

Type species: Actinodendron Loligo Hemprich and Ehrenberg in Ehrenberg, 1834, by monotypy.

Nomenclature notes: Type species is in agreement with Carlgren (1949). Authorship is in agreement with Neave (1940a);

Carlgren(1949) erroneously gave 1857 as the date of publication.

Spelling errors or variants: Phimanthus, Phymantes, Phymantus, Phymathus

Currently considered valid: Yes

Physactis Verrill, 1869b

Type species: Actinia multicolor Stimpson, 1856a, by monotypy.

Nomenclature notes: Authorship is in agreement with Neave (1940a).

Currently considered valid: No

Physobrachia Saville-Kent, 1893

Type species: Physobrachia Douglasi Saville-Kent, 1893, by monotypy.

Nomenclature notes: Authorship is in agreement with Neave (1940a).

Currently considered valid: No

Phytocoetes Annandale, 1915

Type species: Phytocoetes gangeticus Annandale, 1915, by original designation.

Nomenclature notes: Type species is in agreement with Carlgren (1949). Authorship is in agreement with Neave (1940a) and with Carlgren (1949).

Spelling errors or variants: Phytocotes

Currently considered valid: Yes

Phytocœteopsis Panikkar, 1936

Type species: Phytocoteopsis ramunnii Panikkar, 1936, by monotypy.

Nomenclature notes: Type species is in agreement with Carlgren (1949). Authorship is in agreement with Carlgren (1949) and with Neave (1950).

Currently considered valid: No

Plastaphellia Delphy, 1939

Type species: Phellia Panamensis Verrill, 1869a, by replacement. 
Nomenclature notes: Replacement name (ICZN Article 60.2) for the junior homonym Phelliopsis Verrill, 1899c. Authorship of both genera is in agreement with Neave (1950).

Currently considered valid: No

Plotactis Milne Edwards, 1857

Type species: Actinia flava Le Sueur, 1817, by monotypy.

Nomenclature notes: Authorship is in agreement with Neave (1940a).

Currently considered valid: No

Polyopis Hertwig, 1882

Type species: Polyopis striata Hertwig, 1882, by monotypy.

Nomenclature notes: Authorship is in agreement with Neave (1940a).

Currently considered valid: No

Polyparium Korotneff, 1886

Type species: Polyparium ambulans Korotneff, 1886, by monotypy.

Nomenclature notes: Authorship is in agreement with Neave (1940a).

Currently considered valid: No

Polysiphonia Hertwig, 1882

Type species: Polysiphonia tuberosa Hertwig, 1882, by monotypy.

Nomenclature notes: In agreement with Neave (1940a) and NZ 10 (on line), junior homonym of sponge genus Polysiphonia of Pomel, A., 1872 [year not verified], Paléontologie ou Description des Animaux Fossiles de la Province D'Oran volume 5, page 127. Senior homonym of [1] hydrozoan genus Polysiphonia of von Lendenfeld, R., 1885, Über Coelenteraten der Südsee. Zeitschrift für Wissenschaftliche Zoologie 41:641; and [2] sponge genus Polysiphonia of Finks, R. M., 1995, Some new genera of Paleozoic calcareous sponges. University of Kansas Paleontological Contributions, new series, 6:4. Authorship of the actiniarian and Pomel's sponge genus is in agreement with Neave (1940a); authorship of Finks' sponge genus is in agreement with NZ 10 (on line).

Currently considered valid: No

Polystomidium Hertwig, 1882

Type species: Polystomidium patens Hertwig, 1882, by monotypy.

Nomenclature notes: Authorship is in agreement with Neave (1940a).

Spelling errors or variants: Polystomidia

Currently considered valid: No

Porponia Hertwig, 1882

Type species: Porponia elongata Hertwig, 1882, by monotypy.

Nomenclature notes: Authorship is in agreement with Neave (1940a).

Currently considered valid: No

Preactis England in England and Robson, 1984

Type species: Preactis millardae England in England and Robson, 1984, by original designation.

Nomenclature notes: Authorship is in agreement with Edwards et al. (1996).

Currently considered valid: Yes

Protanthea Carlgren, 1891

Type species: Protanthea simplex Carlgren, 1891, by monotypy.

Nomenclature notes: Type species is in agreement with Carlgren (1949). Authorship is in agreement with Neave (1940a) and with Carlgren (1949).

Spelling errors or variants: Prothantea

Currently considered valid: Yes 
Pseudactinia Carlgren, 1928a

Type species: Actinia flagellifera Drayton in Dana, 1846, by original designation.

Nomenclature notes: Carlgren (1949) erroneously gave the type species as Comactis flagellifera, dated from 1882. Authorship is in agreement with Neave (1940) and with Carlgren (1949).

Currently considered valid: Yes

Pseudhormathia Carlgren, 1943

Type species: Pseudhormathia bocki Carlgren, 1943, by monotypy.

Nomenclature notes: Authorship is in agreement with Carlgren (1949) and with Neave (1950).

Currently considered valid: Yes

Pseudoparactis Stephenson, 1920

Type species: Paractis tenuicollis McMurrich, 1904, by monotypy.

Nomenclature notes: Authorship is in agreement with Neave (1940a) and with Carlgren (1949).

Currently considered valid: Yes

Pseudophellia Verrill, 1899d

Type species: Phellia arctica Verrill, 1868, by monotypy.

Nomenclature notes: Authorship is in agreement with Neave (1940a).

Currently considered valid: No

Ptychodactis Appellöf, 1893

Type species: Ptychodactis patula Appellöf, 1893, by monotypy.

Nomenclature notes: Neave (1940a) gave 1894 for the genus but 1893 for the publication; authorship is in agreement with Carlgren (1949).

Currently considered valid: Yes

Pycnanthus McMurrich, 1893

Type species: Pycnanthus maliformis McMurrich, 1893, by monotypy.

Nomenclature notes: Type species is in agreement with Carlgren (1949). Authorship is in agreement with Neave (1940a) and with Carlgren (1949).

Currently considered valid: Yes

Radianthus Kwietniewski, 1896a

Type species: Radianthus Kükenthali Kwietniewski, 1896a, by monotypy.

Nomenclature notes: Type species is in agreement with Carlgren (1949). Authorship is in agreement with Neave (1940b); Carlgren (1949) erroneously gave 1897 as the date of publication.

Currently considered valid: No

Ragactis Andres, 1883

Type species: None

Nomenclature notes: No type species has been designated for this genus; two species were included in it originally. Authorship is in agreement with Neave (1940b).

Currently considered valid: Yes

Ramirezia Zamponi, 1980

Type species: Ramirezia balsae Zamponi, 1980, by original designation.

Nomenclature notes: In agreement with NZ 10 (on line), senior homonym of coleopteran genus Ramirezia of MolinoOlmedo, F., 2001, Cladistica del genero Chiasognathus Stephens, 1831 y Sphaenognathus Buquet, 1838 con proposicion de subgeneros nuevos (Coleoptera: Lucanidae). Revue Chileana Entomol. 28: 85. Authorship of the actiniarian genus is in agreement with Edwards et al. (1996).

Spelling errors or variants: Ramireza

Currently considered valid: Yes 
Raphactis Verrill, 1899b

Type species: Raphactis nitida Verrill, 1899b, by original designation.

Nomenclature notes: Authorship is in agreement with Neave (1940b).

Currently considered valid: No

Rhodactinia Agassiz, 1847

Type species: Actinia Davisii Agassiz, 1847, by monotypy.

Nomenclature notes: Authorship is in agreement with Neave (1940).

Currently considered valid: No

Rhytidactis Pax, 1922

Type species: Rhytidactis antarctica Pax, 1922, by monotypy.

Nomenclature notes: Authorship is in agreement with Neave (1940b).

Currently considered valid: No

Rivetia Pax, 1912

Type species: Actinia papillosa Lesson, 1830, by monotypy.

Nomenclature notes: Authorship is in agreement with Neave (1940b).

Currently considered valid: No

Ropalactis Andres, 1883

Type species: None

Nomenclature notes: No type species has been designated for this genus; two species were included in it originally. Authorship is in agreement with Neave (1940b).

Currently considered valid: No

Saccactis Lager, 1911

Type species: Saccactis Mc Murrichi Lager, 1911, by subsequent designation.

Nomenclature notes: Type species was designated by Riemann-Zürneck and Gallardo (1990). Authorship is in agreement with Neave (1940b).

Currently considered valid: No

Sagartia Gosse, 1855

Type species: Actinia elegans Dalyell, 1848, by subsequent designation.

Nomenclature notes: Type species was designated by Haddon (1889), and is in agreement with Carlgren (1949). Authorship is in agreement with Neave (1940b) and with Carlgren (1949).

Spelling errors or variants: Sagaratia, Sagaria, Sagarta, Sargartia

Currently considered valid: Yes

Sagartianthus Carlgren, 1943

Type species: Sagartianthus indosinensis Carlgren, 1943, by monotypy.

Nomenclature notes: Authorship is in agreement with Carlgren (1949) and with Neave (1950).

Currently considered valid: Yes

Sagartiogeton Carlgren, 1924b

Type species: Sagartiogeton robustus Carlgren, 1924b, by subsequent designation.

Nomenclature notes: Type species was designated by Carlgren (1949). Authorship is in agreement with Neave (1940b) and with Carlgren (1949).

Spelling errors or variants: Sargatiogeton

Currently considered valid: Yes

Sagartiomorphe Kwietniewski, 1898

Type species: Sagartiomorphe carlgreni Kwietniewski, 1898, by monotypy.

Nomenclature notes: Authorship is in agreement with Carlgren (1949); Neave (1940b) erroneously stated Sagartiomor- 
pha [sic] was described by Kwietniewski in 1897.

Spelling errors or variants: Sargartiomorphe, Sagartiomorpha

Currently considered valid: Yes

Sarcophinanthus Lesson, 1830

Type species: None

Nomenclature notes: No type species has been designated for this genus; two species were included in it originally.

Neave (1940b) erroneously stated Sarcophinanthus was described in 1838.

Spelling errors or variants: Sarcophianthus

Currently considered valid: Yes

Scolanthus Gosse, 1853

Type species: Scolanthus callimorphus Gosse, 1853, by monotypy.

Nomenclature notes: Authorship is in agreement with Neave (1940b).

Currently considered valid: Yes

Scyphia Wright, 1859

Type species: Actinia Bellis Ellis and Solander, 1786, by monotypy.

Nomenclature notes: Not listed in NZ (Neave 1939a, b, 1940a, b, 1950; Edwards \& Hopwood 1966; Edwards \& Vevers 1975; Edwards \& Tobias 1993; Edwards et al. 1996; volume 10 on line). Oken, 1815, in which the sponge name Scyphia was published according to Neave (1940b), was rejected for nomenclatorial purposes in Opinion 417 of the International Commission on Zoological Nomenclature (Bulletin of Zoological Nomenclature 14:1-42; September 1956) because the author did not apply the principles of binominal nomenclature.

Currently considered valid: No

Scytophorus Hertwig, 1882

Type species: Scytophorus striatus Hertwig, 1882, by monotypy.

Nomenclature notes: Type species is in agreement with Carlgren (1949). Authorship is in agreement with Neave (1940b) and with Carlgren (1949).

Currently considered valid: Yes

Seepactis Sanamyan and Sanamyan, 2007

Type species: Seepactis galkini Sanamyan and Sanamyan, 2007, by original designation.

Nomenclature notes: Not listed in NZ (volume 10 on line)

Currently considered valid: Yes

Segonzactis Riemann-Zürneck, 1979

Type species: Segonzactis platypus Riemann-Zürneck, 1979, by original designation.

Nomenclature notes: Authorship is in agreement with Edwards et al. (1996).

Spelling errors or variants: Segonsactis

Currently considered valid: Yes

Sicyonis Hertwig, 1882

Type species: Sicyonis crassa Hertwig, 1882, by monotypy.

Nomenclature notes: Type species is in agreement with Carlgren (1949). Authorship is in agreement with Neave (1940b) and with Carlgren (1949).

Currently considered valid: Yes

Sicyopus Gravier, 1918

Type species: Sicyopus commensalis Gravier, 1918, by monotypy.

Nomenclature notes: In agreement with Neave (1940b), junior homonym of Sicyopus of Gill, T., 1864, Description of the gobioid genera of the western coast of temperate North America. Proceedings of the Academy of Natural Sciences of Philadelphia 1863, 262. Authorship of both genera in agreement with Neave (1940b).

Currently considered valid: Yes 
Siphonactinia Danielssen and Koren, 1856

Type species: Siphonactinia Boeckii Danielssen and Koren, 1856, by monotypy.

Nomenclature notes: Neave (1940b) erroneously attributed authorship to Koren and Danielssen.

Currently considered valid: Yes

Siphonactinopsis Carlgren, 1921

Type species: Siphonactinopsis laevis Carlgren, 1921, by monotypy.

Nomenclature notes: Authorship is in agreement with Carlgren (1949); Neave (1940b) erroneously gave 1922 as the date.

Currently considered valid: Yes

Solenactinia Fischer, 1889

Type species: Sagartia erythrochila Fischer, 1874, by monotypy.

Nomenclature notes: Not listed in NZ (Neave 1939a, b, 1940a, b, 1950; Edwards \& Hopwood 1966; Edwards \& Vevers 1975; Edwards \& Tobias 1993; Edwards et al. 1996; volume 10 on line).

Currently considered valid: No

Spheractis England, 1992

Type species: Spheractis cheungae England, 1992, by original designation.

Nomenclature notes: Authorship is in agreement with Edwards et al. (1996).

Currently considered valid: Yes

Spyractis Andres, 1883

Type species: Actinia punctulata Quoy and Gaimard, 1833, by monotypy.

Nomenclature notes: Not listed in NZ (Neave 1939a, b, 1940a, b, 1950; Edwards \& Hopwood 1966; Edwards \& Vevers 1975; Edwards \& Tobias 1993; Edwards et al. 1996; volume 10 on line).

Currently considered valid: Yes

Stauractis Andres, 1883

Type species: Actinodactylus Boscii Duchassaing, 1850, by monotypy.

Nomenclature notes: Actinodactylus Boscii is also type species of Actinodactylus. Authorship is in agreement with Neave (1940b).

Currently considered valid: Yes

Stelidiactis Danielssen, 1890

Type species: None

Nomenclature notes: No type species has been designated for this genus; three species were included in it originally. Neave (1940b) erroneously gave page 19 for the description: the genus was described on page 18.

Spelling errors or variants: Stilidiacis, Stilidiactis

Currently considered valid: No

Stephanactis Verrill, 1869b

Type species: Stephanactis Indica Verrill, 1869b, by monotypy.

Nomenclature notes: In agreement with Neave (1940b), senior homonym of Stephanactis of Hertwig, R., 1882, Die Actinien der Challenger Expedition, page 77.

Currently considered valid: Yes

Stephanactis Hertwig, 1882

Type species: Actinia abyssicola Moseley, 1877, by subsequent designation.

Nomenclature notes: Type species was designated by Verrill (1899b). In agreement with Neave (1940b), junior homonym of Stephanactis of Verrill (1869b). Verrill (1899b) resolved the homonymy by creating a replacement name (ICZN Article 60.2) Stephanauge for Hertwig's genus. Neave (1940b) stated that Stephanactis was described by Hertwig (1882), which is true; however, it appears that the German version of Hertwig's publication on the Challenger anemones appeared before that in the expedition series, which Neave cited. 
Currently considered valid: Yes

Stephanauge Verrill, 1899b

Type species: Actinia abyssicola Moseley, 1877, by replacement.

Nomenclature notes: Replacement name (ICZN Article 60.2) for the junior homonym Stephanactis. Type species is not in agreement with Carlgren (1949). Authorship is in agreement with Neave (1940b) and with Carlgren (1949).

Currently considered valid: Yes

Stephanthus Rodríguez and López-González, 2003

Type species: Stephanthus antarcticus Rodríguez and López-González, 2003, by original designation.

Nomenclature notes: Authorship is in agreement with NZ 10 (on line).

Currently considered valid: Yes

Stephensonactis Panikkar, 1936

Type species: Stephensonactis ornata Panikkar, 1936, by monotypy.

Nomenclature notes: Authorship is in agreement with Carlgren (1949) and with Neave (1950).

Currently considered valid: Yes

Stichodactis Kwietniewski, 1898

Type species: Stichodactis papillosa Kwietniewski, 1898, by monotypy.

Nomenclature notes: Neave (1940b) erroneously rendered the author's name as Knietniewski and gave the date as 1897.

Currently considered valid: No

Stichodactyla Brandt, 1835

Type species: Stichodactyla Mertensii Brandt, 1835, by monotypy.

Nomenclature notes: Type species is in agreement with Dunn (1981). Authorship is in agreement with Neave (1940b).

Currently considered valid: Yes

Stichophora Brandt, 1835

Type species: Stichophora cyanea Brandt, 1835, by monotypy.

Nomenclature notes: Authorship is in agreement with Neave (1940b).

Currently considered valid: Yes

Stoichactis Haddon, 1898

Type species: Discosoma Kenti Haddon and Shackleton, 1893, by subsequent designation.

Nomenclature notes: Type species was designated by Carlgren (1949). Authorship is in agreement with Neave (1940b) and with Carlgren (1949).

Currently considered valid: No

Stomphia Gosse, 1859

Type species: Stomphia Churchia Gosse, 1859, by monotypy.

Nomenclature notes: Type species is not in agreement with Carlgren (1949). Authorship is in agreement with Neave (1940b) and with Carlgren (1949).

Spelling errors or variants: Stomophia

Currently considered valid: Yes

Stylobates Dall, 1903

Type species: Stylobates aeneus Dall, 1903, by monotypy.

Nomenclature notes: Originally described as a gastropod. Authorship is in agreement with Neave (1940b).

Currently considered valid: Yes

Synactinernus Carlgren, 1918

Type species: Synactinernus flavus Carlgren, 1918, by monotypy.

Nomenclature notes: Authorship is in agreement with Carlgren (1949); not listed in NZ (Neave 1939a, b, 1940a, b, 1950; Edwards \& Hopwood 1966; Edwards \& Vevers 1975; Edwards \& Tobias 1993; Edwards et al. 1996; volume 10 on line). 
Currently considered valid: Yes

Synandwakia Carlgren, 1947

Type species: Andwakia Hozawai Uchida, 1932a, by monotypy.

Nomenclature notes: Authorship is in agreement with Carlgren (1949) and with Edwards and Hopwood (1966).

Currently considered valid: Yes

Synantheopsis England, 1992

Type species: Synantheopsis primus England, 1992, by original designation.

Nomenclature notes: Authorship is in agreement with Edwards et al. (1996).

Currently considered valid: Yes

Synanthus Verrill, 1879

Type species: Synanthus mirabilis Verrill, 1879, by monotypy.

Nomenclature notes: Authorship is in agreement with Neave (1940b).

Currently considered valid: No

Synhalcampa Carlgren, 1921

Type species: Halianthus limnicola Annandale, 1915, by monotypy.

Nomenclature notes: Not listed in NZ (Neave 1939a, b, 1940a, b, 1950; Edwards \& Hopwood 1966; Edwards \& Vevers 1975; Edwards \& Tobias 1993; Edwards et al. 1996; volume 10 on line).

Currently considered valid: No

Synhalcampella Carlgren, 1921

Type species: Halcampella Ostroumowi Wyragévitch, 1905, by monotypy.

Nomenclature notes: Authorship is in agreement with Carlgren (1949); not listed in NZ (Neave 1939a, b, 1940a, b, 1950;

Edwards \& Hopwood 1966; Edwards \& Vevers 1975; Edwards \& Tobias 1993; Edwards et al. 1996; volume 10 on line).

Currently considered valid: Yes

Synhalcurias Carlgren, 1914

Type species: Ilyanthopsis elegans Wassilieff, 1908, by monotypy.

Nomenclature notes: Authorship is in agreement with Carlgren (1949); not listed in NZ (Neave 1939a, b, 1940a, b, 1950;

Edwards \& Hopwood 1966; Edwards \& Vevers 1975; Edwards \& Tobias 1993; Edwards et al. 1996; volume 10 on line).

Spelling errors or variants: Symphalcurias

Currently considered valid: Yes

Synphellia Carlgren, 1924a

Type species: Synphellia aucklandica Carlgren, 1924a, by monotypy.

Nomenclature notes: Authorship is in agreement with Neave (1940b).

Currently considered valid: No

Synsicyonis Carlgren, 1921

Type species: Sicyonis elongata Hertwig, 1888, by monotypy.

Nomenclature notes: Authorship is in agreement with Carlgren (1949); not listed in NZ (Neave 1939a, b, 1940a, b, 1950;

Edwards \& Hopwood 1966; Edwards \& Vevers 1975; Edwards \& Tobias 1993; Edwards et al. 1996; volume 10 on line).

Currently considered valid: Yes

Taractea Andres, 1883

Type species: Oulactis Danae Duchassaing de Fonbressin and Michelotti, 1860, by monotypy.

Nomenclature notes: Neave (1940b) erroneously gave 1884 as the date of publication.

Currently considered valid: No

Taractostephanus Brandt, 1835

Type species: Actinia squamosa Bruguiere, 1789, by monotypy. 
Nomenclature notes: Authorship is in agreement with Neave (1940b).

Currently considered valid: No

Tealia Gosse, $1858 \mathrm{~b}$

Type species: Actinia felina Linnaeus, 1767, by subsequent designation.

Nomenclature notes: Type species was designated by Carlgren (1949). Authorship is in agreement with Neave (1940b) and with Carlgren (1949).

Currently considered valid: No

Tealianthus Carlgren, 1927

Type species: Tealianthus incertus Carlgren, 1927, by monotypy.

Nomenclature notes: Authorship is in agreement with Neave (1940b) and with Carlgren (1949).

Currently considered valid: Yes

Tealidium Hertwig, 1882

Type species: Tealidium cingulatum Hertwig, 1882, by monotypy.

Nomenclature notes: Type species is in agreement with Carlgren (1949). Authorship is in agreement with Neave (1940b) and with Carlgren (1949).

Currently considered valid: Yes

Tealiopsis Danielssen, 1890

Type species: Tealiopsis polaris Danielssen, 1890, by monotypy.

Nomenclature notes: Authorship is in agreement with Neave (1940b).

Currently considered valid: No

\section{Telactinia England, 1987}

Type species: Anemonia citrina Haddon and Shackleton, 1893, by original designation.

Nomenclature notes: Not listed in NZ (Edwards et al. 1996; volume 10 on line). Anemonia citrina is also type species of Isactinia Carlgren, 1900a.

Currently considered valid: Yes

Telmatactis Gravier, 1916

Type species: Telmatactis Valle-Flori Gravier, 1916, by monotypy.

Nomenclature notes: Neave (1940b) and Carlgren (1949) erroneously gave 1918 as the date of publication of both type species and genus.

Currently considered valid: Yes

Tetractis Andres, 1883

Type species: Actinia quadrangularis Bruguiere, 1789, by monotypy.

Nomenclature notes: Junior homonym of echinoderm genus Tetractis of Schultze, C. F., 1759, Betrachtung der versteinerten Seesterne, und ihrer Theile, page 49. Neave (1940b) erroneously gave 1760 as the publication date of the echinoderm genus; the actiniarian genus was not listed in NZ (Neave 1939a, b, 1940a, b, 1950; Edwards \& Hopwood 1966; Edwards \& Vevers 1975; Edwards \& Tobias 1993; Edwards et al. 1996; volume 10 on line).

Currently considered valid: Yes

Thalassianthus Rüppell and Leuckart, 1828

Type species: Thalassianthus Aster Rüppell and Leuckart, 1828, by monotypy.

Nomenclature notes: Type species is in agreement with Carlgren (1949). Authorship is in agreement with Neave (1940b); Carlgren (1949) gave only Leuckart as the author.

Spelling errors or variants: Thallasianthus

Currently considered valid: Yes

Thaumactis Fowler, 1888

Type species: Thaumactis medusoides Fowler, 1888, by monotypy. 
Nomenclature notes: Authorship is in agreement with Neave (1940b).

Currently considered valid: No

Thelaceros Mitchell, 1890

Type species: Thelaceros rhizophora Mitchell, 1890, by monotypy.

Nomenclature notes: Authorship is in agreement with Neave (1940b).

Currently considered valid: No

Thelactis Klunzinger, 1877

Type species: Thelactis simplex Klunzinger, 1877, by monotypy.

Nomenclature notes: Authorship is in agreement with Neave (1940b).

Currently considered valid: Yes

Thoe Wright, 1859

Type species: None

Nomenclature notes: No type species has been designated for this genus; three species were included in it originally. Neave (1940b) rendered with an umlaut as senior homonym crustacean genus Thoё of Bell, T., 1836, Some account of the Crustacea of the coasts of South America. Proceedings of the Scientific Meetings of the Zoological Society of London 3:170. Neave (1940b) rendered without an umlaut as junior homonyms [1] polychaete genus Thoe of Kinberg, J. G. H., 1866, Annulata nova. Öfversigt af Kongl. Vetenskaps-Akademiens Förhandlingar 1865:249; and [2] ctenophore genus Thö̈ of Chun, C., 1878, Die im Golf von Neapel erscheinenden Rippenquallen. Mittheilungen aus der Zoologischen Station zu Neapel 1:199. Authorship of the actiniarian and crustacean genera is in agreement with Neave (1940b), who erroneously gave 1865 as the publication date of the polychaete.

Spelling errors or variants: Thö̈

Currently considered valid: No

Tilesia Andres, 1883

Type species: Actinia Brasiliensis Milne Edwards, 1857, by monotypy.

Nomenclature notes: Junior homonym of [1] bryozoan genus Tilesia of Lamouroux, J., 1821, Exposition Méthodique des Genres de l'Ordre des Polypiers: avec leur description et celle des principales espèces, figurées dans 84 planches, les 63 premières appartenant a l'Histoire naturelle des zoophytes d'Ellis et Solander, page 42; [2] fish genus Tilesia of Swainson, W., 1838, On the Natural History of Fishes, Amphibians, \& Reptiles or Monocardian Animals, volume 1, page 318; and [3] dipteran genus Tilesia of Robineau-Desvoidy, J. B., 1863, Histoire naturelle des diptères des environs de Paris 2:364-366. Authorship of the non-actiniarian genera is in agreement with Neave (1940b). The actiniarian name not listed in NZ (Neave 1939a, b, 1940a, b, 1950; Edwards \& Hopwood 1966; Edwards \& Vevers 1975; Edwards \& Tobias 1993 ; Edwards et al. 1996; volume 10 on line).

Currently considered valid: Yes

Triactis Klunzinger, 1877

Type species: Triactis producta Klunzinger, 1877, by monotypy.

Nomenclature notes: Type species is in agreement with Carlgren (1949). In agreement with Neave (1940b), senior homonym of protist genus Triactis of Haeckel, E., 1882, Entwurf eines Radiolarien-Systems auf Grund von Studien der Challenger-Radiolarien. Jenaische Zeitschrift für Naturwissenschaft 15:457. Authorship of the actiniarian genus is in agreement with Carlgren (1949) and with Neave (1940b), who erroneously gave the date of the radiolarian genus as 1881 .

Currently considered valid: Yes

Tricnidactis de Oliveira Pires, 1987

Type species: Tricnidactis errans de Oliveira Pires, 1987, by monotypy.

Nomenclature notes: Edwards et al. (1996) listed as homonyms Tricnidactis of de Olivera Pires in 1987 and 1988 ; the two refer to the same species, the first publication being an abstract from a meeting but fulfilling the criteria of availability, and the second being an extended treatment written as an original description.

Currently considered valid: Yes 
Urophysalus Costa, 1869

Type species: Urophysalus Grubii Costa, 1869, by monotypy.

Nomenclature notes: Originally described as a sipunculid. Authorship is in agreement with Neave (1940b).

Currently considered valid: No

Urticina Ehrenberg, 1834

Type species: Actinia crassicornis Müller, 1776, by subsequent designation.

Nomenclature notes: Type species was designated by Manuel (1981). Authorship is in agreement with Neave (1940b).

Currently considered valid: Yes

Urticinopsis Carlgren, 1927

Type species: Urticina antarctica Verrill, 1922, by monotypy.

Nomenclature notes: Type species is in agreement with Carlgren (1949). Authorship is in agreement with Neave (1940b) and with Carlgren (1949).

Currently considered valid: Yes

Verrillactis England, 1971

Type species: Sagartia Paguri Stimpson in Verrill, 1869b, by original designation.

Nomenclature notes: Authorship is in agreement with Edwards and Tobias (1993).

Currently considered valid: Yes

Viatrix Duchassaing de Fonbressin and Michelotti, 1860

Type species: Urticina globulifera Duchassaing, 1850, by monotypy.

Nomenclature notes: Authorship is in agreement with Neave (1940).

Currently considered valid: No

Xanthiopus Keferstein, 1862

Type species: None

Nomenclature notes: No type species has been designated for this genus; two species were included in it originally. Authorship is in agreement with Neave (1940b).

Currently considered valid: No

Zaolutus Hand, 1955

Type species: Zaolutus actius Hand, 1955, by monotypy.

Nomenclature notes: Authorship is in agreement with Edwards and Hopwood (1966).

Currently considered valid: Yes

\section{GENERA OF CORALLIMORPHARIA (coral-like sea anemones)}

Actinodiscus de Blainville, 1830

Type species: Discosoma nummiforme Rüppell and Leuckart, 1828, by monotypy.

Nomenclature notes: Type species is in agreement with Carlgren (1949). In agreement with Edwards et al. (1996), senior homonym of echinoderm genus Actinodiscus of Smith, A. B. and C. R. C. Paul, 1982, Revision of the class Cyclocystoidea (Echinodermata). Philosophical Transactions of the Royal Society of London B 298(1083):625. Authorship of the corallimorpharian genus is in agreement with Neave (1939a) and with Carlgren (1949), and that of the echinoderm genus with Edwards et al. (1996).

Currently considered valid: Yes

Actinotryx Duchassaing de Fonbressin and Michelotti, 1860

Type species: Actinotryx Sancti Thomae Duchassaing de Fonbressin and Michelotti, 1860, by monotypy.

Nomenclature notes: Authorship is in agreement with Neave (1939a).

Spelling errors or variants: Actinothrix, Actinothryx, Actinotrynx 
Amplexidiscus Dunn and Hamner, 1980

Type species: Amplexidiscus fenestrafer Dunn and Hamner, 1980, by monotypy.

Nomenclature notes: Authorship is in agreement with Edwards et al. (1996).

Currently considered valid: Yes

Chalmersia Delage and Hérouard, 1901

Type species: None

Nomenclature notes: This is a nomen nudum: an available species name was not assigned in combination with this genus name (ICZN Article 12.2.5).

Currently considered valid: No

Corallimorphus Moseley, 1877

Type species: Corallimorphus profundus Moseley, 1877, by subsequent designation.

Nomenclature notes: Type species was designated by Carlgren (1949) and is in agreement with Fautin (1984). Authorship is in agreement with Neave (1939a) and with Carlgren (1949).

Currently considered valid: Yes

Corynactis Allman, 1846

Type species: Corynactis viridis Allman, 1846, by monotypy.

Nomenclature notes: Type species is in agreement with Carlgren (1949). Authorship is in agreement with Neave (1939a) and with Carlgren (1949).

Currently considered valid: Yes

Discosoma Rüppell and Leuckart, 1828

Type species: Discosoma nummiforme Rüppell and Leuckart, 1828, by monotypy.

Nomenclature notes: In agreement with Neave (1939b), senior homonym of [1] arachnid genus Discosoma of Perty, M., 1833, Delectus animalium articulatorum, quae in itinere per Brasiliam, 3:209; [2] mollusc genus Discosoma of Paetel, G., 1875, Die bisher veröffentlichten Familien- und Gattungsnamen der Mollusken, page 71; and [3] protist genus Discosoma of Swarczewsky, B., 1928, Zur Kenntnis der Baikalprotistenfauna. Die an den Baikalgammariden lebenden Infusorien. II. Dendrocometidae. Archiv für Protistenkunde 62:52. Authorship of all genera is in agreement with Neave (1939b).

Spelling errors or variants: Discossoma

Currently considered valid: Yes

Draytonia Duchassaing de Fombressin and Michelotti, 1864

Type species: Draytonia myrcia Duchassaing de Fombressin and Michelotti, 1864, by monotypy.

Nomenclature notes: Authorship is in agreement with Neave (1939b).

Currently considered valid: No

Isocorallion Carlgren, 1900a

Type species: Isocorallion Hertwigi Carlgren, 1900a, by monotypy.

Nomenclature notes: Authorship is in agreement with Neave (1939b).

Spelling errors or variants: Isocorallium

Currently considered valid: No

Metarhodactis Carlgren, 1943

Type species: Metarhodactis boninensis Carlgren, 1943, by monotypy.

Nomenclature notes: Authorship is in agreement with Carlgren (1949) and with Neave (1950).

Currently considered valid: Yes 
Nectactis Gravier, 1918

Type species: Nectactis singularis Gravier, 1918, by monotypy.

Nomenclature notes: Authorship is in agreement with Neave (1940a) and with Carlgren (1949).

Currently considered valid: Yes

Orinia Duchassaing de Fonbressin and Michelotti, 1860

Type species: Orinia torpida Duchassaing de Fonbressin and Michelotti, 1860, by monotypy.

Nomenclature notes: Authorship is in agreement with Neave (1940a) and with Carlgren (1949).

Currently considered valid: No

Phialactis Fowler, 1888

Type species: Phialactis neglecta Fowler, 1888, by monotypy.

Nomenclature notes: Authorship is in agreement with Neave (1940a).

Currently considered valid: No

Platyzoanthus Saville-Kent, 1893

Type species: Platyzoanthus mussoides Saville-Kent, 1893, by monotypy.

Nomenclature notes: Authorship is in agreement with Neave (1940a).

Currently considered valid: Yes

Pseudocorynactis den Hartog, 1980

Type species: Pseudocorynactis caribbeorum den Hartog, 1980, by monotypy.

Nomenclature notes: Authorship is in agreement with Edwards et al. (1996).

Currently considered valid: Yes

Rhodactis Milne Edwards and Haime, 1851

Type species: Metridium rhodostomum Hemprich and Ehrenberg in Ehrenberg, 1834, by monotypy.

Nomenclature notes: Type species is in agreement with Carlgren (1949). Authorship is in agreement with Neave (1940b) and with Carlgren (1949).

Spelling errors or variants: Rodactis

Currently considered valid: Yes

Ricordea Duchassaing de Fonbressin and Michelotti, 1860

Type species: Ricordea florida Duchassaing de Fonbressin and Michelotti, 1860, by monotypy.

Nomenclature notes: Authorship is in agreement with Neave (1940b) and with Carlgren (1949).

Spelling errors or variants: Ricordia

Currently considered valid: Yes

Sideractis Danielssen, 1890

Type species: Sideractis glacialis Danielssen, 1890, by monotypy.

Nomenclature notes: Authorship is in agreement with Neave (1940b) and with Carlgren (1949).

Currently considered valid: Yes

Sphincteractis Zamponi, 1976

Type species: Sphincteractis sanmatiensis Zamponi, 1976, by monotypy.

Nomenclature notes: Edwards and Tobias (1993) erroneously gave the date as 1977.

Currently considered valid: No 


\section{Acknowledgments}

This research was supported by a Research Experience for Undergraduates supplement to US National Science Foundation grant EF05-31779 (Cartwright, Collins, and Fautin, in the program Assembling the Tree of Life), and by grants DEB99-78106 and DEB95-21819 (Fautin, in the program Partnerships for Enhancing Expertise in Taxonomy). We are grateful for assistance by Katie Soldan and Carla Marrs.

\section{Literature cited}

Adams, J. (1800) Descriptions of some marine animals found on the coast of Wales. Transactions of the Linnean Society (London), 5, 7-12.

Agassiz, L. (1847) Lettre de M. Louis Agassiz, datée de Boston, le 30 septembre 1847, adressée à M. Alexandre de Humboldt. Comptes Rendus de l'Academie des Sciences, Paris, 25, 677-682.

Agassiz, L. (1859) On some new actinoid polyps of the coast of the United States. Proceedings of the Boston Society of Natural History, 7, 23-24.

Allman, G. J. (1846) Biological contributions. Description of a new genus of helianthoid zoophytes. Annals and Magazine of Natural History, 17, 417-419.

Andres, A. (1881) Prodromus neapolitanae actiniarum faunae addito generalis actiniarum bibliographiae catalogo. Mitteilungen aus der Zoologischen Station zu Neapel, 2, 305-371.

Andres, A. (1883) Le Attinie (Monografia). Coi Tipi der Salviucci, Roma, 460.

Annandale, N. (1907) The fauna of brackish ponds at Port Canning, Lower Bengal. Part III. —An isolated race of the actinian Metridium schillerianum (Stoliczka). Records of the Indian Museum, 1, 47-74.

Annandale, N. (1915) Fauna of the Chilka Lake. The coelenterates of the lake, with an account of the Actiniaria of brackish water in the Gangetic Delta. Memoirs of the Indian Museum, 5, 65-114.

Appellöf, A. (1893) Ptychodactis patula n. g. \& sp. der Repräsentant einer neuen Hexactinien-Familie. Bergens Museums Aarbog, 1893, 3-22.

Belém, M. J., Herrera Moreno, A., Schlenz, E. (1996) On Isoaulactinia stelloides (McMurrich, 1889), n. gen., n. comb. (Cnidaria; Actiniaria; Actiniidae). Biociências, 4, 77-88.

de Blainville, H. M. (1824) Metridium. Dictionnaire des Sciences Naturelles, F. G. Levrault, Strasbourg, 470.

de Blainville, H. M. (1830) Dictionnaire des Sciences Naturalles. F.G. Levrault, Strasbourg, Paris, 631.

Bourne, G. C. (1918) On some new Phelliinae from New Guinea. Quarterly Journal of Microscopical Science, 63, 3190.

Boveri, T. (1893) Das Genus Gyractis, eine radial-symmetrische Actinienform. Zoologische Jahrbücher Abteilung für Systematik, 7, 241-253.

Brandt, J. F. (1835) Polypos, acalephas discophoras et siphonophoras, nec non echinodermata continens. Prodromus Descriptionis Animalium AB H. Mertensio in Orbis Terrarum Circumnavigatione Observatorum, Sumptibus Academiae, Petropoli, 75.

Bruguiere (1789) Encyclopédie Méthodique. Histoire Naturelle des Vers. Libraire Panckouke, Paris, 757.

Busch, W. (1851) Beobachtungen Über Anatomie und Entwickelung Einiger Wirbellosen Seethiere. August Hirschwald, Berlin, 143.

Cappola, V. A., Fautin, D. G. (2000) All three species of Ptychodactiaria belong to order Actiniaria (Cnidaria: Anthozoa). Journal of the Marine Biological Association of the UK, 80, 995-1005.

Carlgren, O. (1891) Protanthea simplex n. gen. n. sp., eine eigentümliche Actinie. Vorläufige Mitteilung. Öfversigt af Kongliga Vetenskaps-Akademiens Förhandlingar, 48, 81-89.

Carlgren, O. (1892) Beiträge zur Kenntnis der Edwardsien. Öfversigt af Kongliga Vetenskaps-Akademiens Förhandlingar, 1892, 451-461.

Carlgren, O. (1893) Studien über Nordische Actinien. Kungliga Svenska Vetenskaps-Akademiens Handlingar, $25,1-148$.

Carlgren, O. (1897) Zur Mesenterienentwicklung der Aktinien. Öfversigt af Kongliga Vetenskaps-Akademiens Förhandlingar, 1897, 159-172.

Carlgren, O. (1899a) Über abschnürbare Tentakel bei den Actiniarien. Zoologischer Anzeiger, 22, 39-44.

Carlgren, O. (1899b) Zoantharien. Hamburger Magalhaensische Sammelreise, 4, 1-48.

Carlgren, O. (1900a) Ostafrikanische Actinien. Gesammelt von Herrn Dr. F. Stuhlmann 1888 und 1889. Mittheilungen aus dem Naturhistorischen Museum, 17, 21-144 [reprint 1-124].

Carlgren, O. (1900b) Über Pentactinia californica n. gen. n. sp. Öfversigt af Kongliga Vetenskaps-Akademiens Förhandlingar, 57, 1165-1172. 
Carlgren, O. (1901) Die Brutpflege der Actiniarian. Biologischen Centralblatt, 21, 468-484.

Carlgren, O. (1902) Die Actiniarien der Olga-Expedition (article IV in Zool. Ergeb. Untersuchungsfahrt deutsch. Seefisch.-Vereins nach der Bäreninsel und Westspitzbergen Sommer 1898 auf SMS “Olga”). Wissenschaftliche Meeresuntersuchungen, Abteilung Helgoland, 5, 33-56.

Carlgren, O. (1911) Über Dactylanthus (Cystiactis) antarcticus (Clubb) zugleich ein Beitrag zur Phylogenie der Actiniarien. Wissenschaftliche Ergebnisse der Schwedischen Südpolarexpedition, 1901-1903, 6, Zool. II, 1-31.

Carlgren, O. (1914) On the genus Porponia and related genera, Scottish National Antarctic Expedition. Transactions of the Royal Society of Edinburgh, 50, 49-71.

Carlgren, O. (1918) Die Mesenterienanordnung der Halcuriiden. Kungliga Fysiografiska Sällskapets Handlingar, 29, 137.

Carlgren, O. (1921) Actiniaria Part I. Danish Ingolf-Expedition, 5, 1-241.

Carlgren, O. (1924a) Actiniaria from New Zealand and its Subantarctic Islands [article XXI in Papers from Dr. Th. Mortensen's Pacific Expedition 1914-16]. Videnskabelige Meddelelser fra Dansk Naturhistorisk Forening (Copenhagen), 77, 179-261.

Carlgren, O. (1924b) Description de deux Actiniaria. Bulletin de l'Institut Océanographique (Monaco), 26-28.

Carlgren, O. (1925a) On the actiniarian family Amphianthidae. Arkiv für Zoologi, 17B, 1-6.

Carlgren, O. (1925b) Zur Kenntnis der Hexacorallen. Zoologischer Anzeiger, 65, 87-99.

Carlgren, O. (1927) Actiniaria and Zoantharia. In: T. Odhner, Further Zoological Results of the Swedish Antarctic Expedition 1901-1903 , P.A. Norstedt \& Söner, Stockholm, 1-102.

Carlgren, O. (1928a) Actiniaria der Deutschen Tiefsee-Expedition. Wissenschaftliche Ergebnisse der Deutschen TiefseeExpedition auf dem Dampfer "Valdivia” 1898-1899, 22, 125-266 [reprint 1-144].

Carlgren, O. (1928b) Ceriantharier, Zoantharier och Actiniarier. Meddelelser om Grønland, 23 Suppl., 253-308.

Carlgren, O. (1932) Die Ceriantharien, Zoantharien und Actiniarien des arktischen Gebietes. In: Fritz Römer, Fritz Schaudinn, August Brauer, and Walther Arndt, Eine Zusammenstellung der arktischen Tierformen mit besonderer Berücksichtigung des Spitzbergen-Gebietes auf Grund der Ergebnisse der Deutschen Expedition in das Nördliche Eismeer im Jahre 1898 , Gustav Fischer, Jena, 255-266.

Carlgren, O. (1934a) Ceriantharia, Zoantharia and Actiniaria from the "Michael Sars" North Atlantic Deep-sea Expedition 1910. Report on the Scientific Results of the "Michael Sars" North Atlantic Deep-Sea Expedition 1910, 5, 1-27.

Carlgren, O. (1934b) Some Actiniaria from Bering Sea and Arctic waters. Journal of the Washington Academy of Sciences, 24, 348-353.

Carlgren, O. (1934c) Zur Revision der Actiniarien. Arkiv für Zoologi, 26A, 1-36.

Carlgren, O. (1937) A new actinian. Smithsonian Miscellaneous Collections, 91, 1-4.

Carlgren, O. (1938) South African Actiniaria and Zoantharia. Kungliga Svenska Vetenskaps-Akademiens Handlingar, 17, $1-148$.

Carlgren, O. (1940) Eastern Pacific Expeditions of the New York Zoological Society. XIX. Actiniaria from the Gulf of California. Zoologica, 25, 211-219.

Carlgren, O. (1942) Actiniaria Part II. Danish Ingolf-Expedition, 5, 1-92.

Carlgren, O. (1943) East-Asiatic Corallimorpharia and Actiniaria. Kungliga Svenska Vetenskaps-Akademiens Handlingar, 20, 1-43.

Carlgen, O. (1945) Further contributions to the knowledge of the cnidom in the Anthozoa especially in the Actiniaria. Kungliga Fysiografiska Sällskapets Handlingar, 56, 1-24.

Carlgren, O. (1947) Further contributions to a revision of the Actiniaria and Corallimorpharia. Arkiv für Zoologi, 17, 117.

Carlgren, O. (1949) A survey of the Ptychodactiaria, Corallimorpharia and Actiniaria. Kungliga Svenska VetenskapsAkademiens Handlingar, series 4, 1(1), 1-121.

Carlgren, O. (1950a) Actiniaria and Corallimorpharia. Scientific Reports on the Great Barrier Reef Expedition 1928-29, $5,427-457$.

Carlgren, O. (1950b) Actiniaria and Zoantharia from South Australia. Arkiv für Zoologi, 20, 121-135 [reprint 1-15].

Carlgren, O. (1950c) Corallimorpharia, Actiniaria and Zoantharia from New South Wales and South Queensland. Arkiv für Zoologi, 1, 131-146.

Carlgren, O. (1951) The actinian fauna of the Gulf of California. Proceedings of the United States National Museum, $101,415-449$.

Carlgren, O. (1956) Actiniaria from depths exceeding 6000 meters. Galathea Reports, 2, 9-16.

Carlgren, O. (1959) Reports of the Lund University Chile Expedition 1948-49 38. Corallimorpharia and Actiniaria with description of a new genus and species from Peru. Arkiv für Zoologi, 71, 1-38.

Carlgren, O., Hedgpeth, J. W. (1952) Actiniaria, Zoantharia and Ceriantharia from Shallow Water in the northwestern Gulf of Mexico. Publications of the Institute of Marine Science (University of Texas), 2, 143-172.

Carpenter, W. B., Jeffreys, J. G. (1871) Report on the deep-sea researches carried on during the months of July, August, and September 1870, in H.M. surveying-ship "Porcupine". Proceedings of the Royal Society of London, 19, 146- 
221.

Clubb, J. A. (1908) Coelentera. National Antarctic Expedition 1901-1904 Natural History, IV. - Actiniae, 1-12.

Contarini, C. N. (1844) Trattato delle attinie, ed osservazioni sopra alcune di esse viventi nei Contorni di Venezia. Stabilimento Di G. Antonelli, Venice, 198.

Costa, A. (1869) Di un genere di Siponculidei. Annuario del'Instituto e Museo di Zoologia dell'Universitá di Napoli, 5, 56-57.

Cutress, B. D. (1961) Habrosanthus bathamae, n. gen., n. sp. (Actiniaria: Sagartiidae) from New Zealand. Transactions of the Royal Society of New Zealand, 1, 95-101.

Cuvier, G. (1817) Le Régne Animal,Volume 4, les Zoophytes. Deterville, Paris.

Dall, W. H. (1903) A new genus of Trochidae. Nautilus, 17, 61-62.

Dalyell, J. G. (1848) Rare and Remarkable Animals of Scotland. John Van Voorst, Paternoster Row, London, 322.

Dana, J. D. (1846) Zoophytes. Volume VII of the United States Exploring Expedition. During the Years 1838, 1839, 1840, 1841, 1842. Under the command of Charles Wilkes, U.S.N. Lea and Blanchard, Philadelphia, 740.

Danielssen, D. C. (1887) Actinida of the Norwegian North-Atlantic Expedition. preliminary report. Bergens Museums Aarbok [also known as Arbok for Universitetet I Bergen], 1887, 1-24.

Danielssen, D. C. (1890) Actinida. Den Norske Nordhavs-Expedition 1876-1878. Zoologi. Grøndahl and Søn, Christiania, 184.

Danielssen, D. C., Koren, J. (1856) Nye Actinier [Actinies nouvelles]. In: M. Sars, J. Koren, D. C. Danielssen, Fauna Littoralis Norvegiae, Fr. D. Beyer, Bergen, 87-90.

Delage, Y., Hérouard, E. (1901) Traité de Zoologie Concrète. C. Reinwald, Paris, 848.

Delle Chiaje, S. (1825) Memorie su la storia e la notomia degli animali senza vertebre die Reprio di Napoli. Stamperia de' Fratelli Fernandes, Napoli, 444.

Delphy, J. (1938) Les actinies athénaires (Actiniaria Athenaria) de la faune Française. Bulletin du Muséum National d'Histoire Naturelle (Paris), 10, 619-622.

Delphy, J. (1939) Présence sur la côte Française de la Manche de l'actinie Bolocera Tuediæ (Johnston) et quelques remarques sur d'autres anthozoaires. Bulletin du Muséum National d'Histoire Naturelle (Paris), 11, 267-270.

Doumenc, D. A., Van-Praët, M. (1988) Actinies abyssales d'un site hydrothermal du Pacifique oriental. Oceanologica Acta, Special 8-Biologie et icologie des sources hydrothermales, 61-68.

Dube, V. M. (1983) Contribuição ao estudo de anêmonas-do-mar do esta do da bahia. Natura, 83, 82-93.

Duchassaing, P. (1850) Animaux Radiaires des Antilles. Plon Fréres, Paris, 33.

Duchassaing de Fombressin, P., Michelotti, G. (1864) Supplément au mémoire sur les Coralliaires des Antilles. Imprimerie Royale, Turin, 112.

Duchassaing de Fonbressin, P., Michelotti, G. (1860) Mémoire sur les Coralliaires des Antilles. Imprimerie Royale, Turin, 89.

Duerden, J. E. (1900) Jamaican Actiniaria. Part II. - Stichodactylinæ and Zoantheæ. Scientific Transactions of the Royal Dublin Society, 7, 133-208.

Dufaure, J. P. (1959) Une nouvelle actinie: Parastephanauge paxi, gen. nov., sp. nov. Bulletin de la Societé Zoologique de France, 84, 86-91.

Dunn, D. F. (1981) The clownfish sea anemones: Stichodactylidae (Coelenterata: Actiniaria) and other sea anemones symbiotic with pomacentrid fishes. Transactions of the American Philosophical Society, 71, 1-115.

Dunn, D. F. (1983) Some Antarctic and sub-Antarctic sea anemones (Coelenterata: Ptychodactiaria and Actiniaria). Antarctic Research Series, 39(1), 1-67.

Dunn, D. F., Hamner, W. M. (1980) Amplexidiscus fenestrafer n. gen., n. sp. (Coelenterata: Anthozoa), a tropical IndoPacific Corallimorpharian. Micronesica, 16, 29-36.

Edwards, M. A., Hopwood, A. T. (1966) Nomenclator Zoologicus vol. VI. Zoological Society of London, London, 329.

Edwards, M. A., Manly, P., Tobias, M. A. (1996) Nomenclator Zoologicus vol. IX. Zoological Society of London, London, 701.

Edwards, M. A., Tobias, M. A. (1993) Nomenclator Zoologicus vol. VIII. Zoological Society of London, London, 620.

Edwards, M. A., Vevers, H. G. (1975) Nomenclator Zoologicus vol. VII. Zoological Society of London, London, 374.

Ehrenberg, C. G. (1834) Beiträge zur physiologischen Kenntniss der Corallenthiere im allgemeinen, und besonders des rothen Meeres, nebst einem Versuche zur physiologischen Systematik derselben. Abhandlungen der Königlichen Akademie der Wissenschaften zu Berlin, 1, 225-380.

Ellis, J. (1768) An account of the Actinia sociata, or clustered animal-flower, lately found on the sea-coasts of the newceded islands. Philosophical Transactions of the Royal Society of London, 57, 428-437.

Ellis, J., Solander, D. (1786) The Natural History of Many Curious and Uncommon Zoophytes, Collected from Various Parts of the Globe. Benjamin White and Son, London, 206.

England, K. W. (1971) Actiniaria from Mururoa Atoll Tuamotu, Polynesia (Hormathiidae; Calliactis polypus Sagartiidae: Verrillactis n. gen. paguri). Cahiers du Pacifique, 15, 23-40.

England, K. W. (1987) Certain Actiniaria (Cnidaria, Anthozoa) from the Red Sea and tropical Indo-Pacific Ocean. Bulle- 
tin of the British Museum (Natural History), 53, 205-292.

England, K. W. (1990) Description of two new mud-dwelling actiniids from Maharashtra, India: Edwardsia athalyei sp. nov. and Acontiactis gen. nov. gokhaleae sp. nov. and a note on Edwardsioides mammillata (Bourne, 1916) (Cnidaria: Actiniaria). Indo-Malayan Zoology, 6, 141-158.

England, K. W. (1992) Actiniaria (Cnidaria: Anthozoa) from Hong Kong with additional data on similar species from Aden, Bahrain and Singapore. In: B. Morton, The Marine Flora and Fauna of Hong Kong and Southern China III, Hong Kong University Press, Hong Kong, 49-95.

England, K. W., Robson, E. A. (1984) A new sea anemone from South Africa (Anthozoa, Ptychodactiaria). Annals of the South African Museum, 94, 305-329.

Fabricius, J. C. (1780) Fauna Groenlandica. Ioannis Gottlob Rothe, Hafniae and Lipsiae, 452.

Farquhar, H. (1898) Preliminary account of some New-Zealand Actiniaria. Journal of theLinnean Society of London (Zoology), 26, 527-536.

Fautin, D. G. (1998) Class Anthozoa: orders Actiniaria, Ceriantharia, and Zoanthinaria. In: Scott, P. V., Blake, J. A., Taxonomic Atlas of the Benthic Fauna of the Santa Maria Basin and Western Santa Barbara Channel, volume 3 (The Cnidaria), Santa Barbara Museum of Natural History, Santa Barbara, 113-139 (chapter 3).

Fautin, D. G. (2005) Three species of intertidal sea anemones (Anthozoa: Actiniidae) from the tropical Pacific: description of Anthopleura buddemeieri n. sp., with remarks on Anthopleura asiatica and Gyractis sesere. Pacific Science 59, 379-391.

Fautin, D. G. (2007) Hexacorallians of the World. http://geoportal.kgs.ku.edu/hexacoral/anemone2/index.cfm. (Consulted most recently 7 November 2007)

Fautin, D. G., Barber, B. R. (1999) Maractis rimicarivora, a new genus and species of sea anemone (Cnidaria: Anthozoa: Actiniaria: Actinostolidae) from an Atlantic hydrothermal vent. Proceedings of the Biological Society of Washington, 112, 624-631.

Fautin, D. G., Hessler, R. R. (1989) Marianactis bythios, a new genus and species of actinostolid sea anemone (Coelenterata: Actiniaria) from the Mariana vents. Proceedings of the Biological Society of Washington, 102, 815-825.

Fautin, D. G., White, T. R., Pearson, K. E. (2002) Two new species of deep-water Corallimorpharia (Cnidaria: Anthozoa) from the northeast Pacific, Corallimorphus denhartogi and C. pilatus. Pacific Science 56, 113-124.

Fischer, P. (1874) Recherches sur les actinies des cotes océaniques de France. Nouvelles Archives du Museum d'Histoire Naturelle de Paris, 10, 193-244.

Fischer, P. (1887) Contribution a l'Actinologie Française. Archives de Zoologie Expérimentale et Générale, 5, 381-442.

Fischer, P. (1888) Description d'une Nouvelle Espèce du Genre Edwardsia Quatrefages. Bulletin de la Societé Zoologique de France, 13, 22-23.

Fischer, P. (1889) Nouvelle Contribution à l'Actinologie Française. Première Partie. Actes de la Société Linnéenne de Bordeaux, 43, 252-309.

Forbes, E. (1840) On the British Actiniadae. Annals and Magazine of Natural History, 5, 180-184.

Forbes, E. (1841) Contributions to British actinology. I. On Kapnea, a new helianthoid polype. Annals and Magazine of Natural History, 7, 81-85.

Forsskål, P. (1775) Descriptiones Animalium Avium, Amphibiorum, Piscium, Insectorum, Vermium; Quae in Itinere Orientali Observait. Mölleri, Havniæ, 164.

Fowler, G. H. (1888) Two new types of Actiniaria. Quarterly Journal of Microscopical Science, 29, 143-152.

Fowler, G. H. (1894) Octineon Lindahli (W. B. Carpenter): an undescribed anthozoon of novel structure. Quarterly Journal of Microscopical Science, 35, 461-480.

Gaertner, J. (1762) An account of the Urtica Marina. Philosophical Transactions of the Royal Society of London, 52, 7585.

Gosse, P. H. (1853) Notes on some new or little-known marine animals. (No. 2). Annals and Magazine of Natural History, 12, 153-159.

Gosse, P. H. (1855) Description of Peachia hastata, a new genus and species of the class Zoophyta; with observations on the family Actiniadae. Transactions of the Linnean Society (London), 21, 267-276.

Gosse, P. H. (1856) On Edwardsia carnea, a new British Zoophyte. Annals and Magazine of Natural History, 18, 219221.

Gosse, P. H. (1858a) Characters and descriptions of some new British sea-anemones. Annals and Magazine of Natural History, 2, 192-196.

Gosse, P. H. (1858b) Synopsis of the families, genera, and species of the British Actiniae. Annals and Magazine of Natural History, 1, 414-419.

Gosse, P. H. (1859) Characters and descriptions of some new British sea-anemones. Annals and Magazine of Natural History, 3, 46-50.

Gosse, P. H. (1860) A History of the British Sea-Anemones and Corals. Van Voorst, Paternoster Row, London, 362.

Gosse, P. H. (1865) On Ageon alfordi, a new British sea-anemone. Annals and Magazine of Natural History, 16, 41-44.

Gravier, C. (1916) Sur un type nouveau d'actinie de l'ile San Thomé (Golfe de Guinée). Bulletin du Muséum National 
d'Histoire Naturelle (Paris), 22, 234-236.

Gravier, C. (1918) Note préliminaire sur les hexactiniaires recueillis au cours des croisières de la Princesse-Alice et de l'Hirondelle de 1888 à 1913 inclusivement. Bulletin de l'Institut Océanographique (Monaco), 1-24.

Haddon, A. C. (1886) First report on the marine fauna of the south-west of Ireland. Actinozoa. Proceedings of the Royal Irish Academy, 4, 615-618.

Haddon, A. C. (1888) On two species of Actiniae from the Mergui Archipelago, collected for the Trustees of the Indian Museum, Calcutta, by Dr. John Anderson, F.R.S., Superintendent of the Museum. Journal of the Linnean Society of London (Zoology), 21, 247-255.

Haddon, A. C. (1889) A revision of the British Actiniae. Part I. Scientific Transactions of the Royal Dublin Society, 4, 297-361.

Haddon, A. C. (1898) The Actiniaria of Torres Straits. Scientific Transactions of the Royal Dublin Society, 6, 393-520.

Haddon, A. C., Duerden, J. E. (1896) On some Actiniaria from Australia and other districts. Transactions of the Royal Dublin Society, 6, 139-172.

Haddon, A. C., Shackleton, A. M. (1893) Description of some new species of Actiniaria from Torres Straits. Scientific Transactions of the Royal Dublin Society, 8, 116-131.

Haeckel, E. (1876) Arabische Korallen. Georg Reimer, Berlin, 49.

Hand, C. (1955) The sea anemones of central California Part II. The endomyarian and mesomyarian anemones. Wasmann Journal of Biology, 13, 37-99.

Hand, C. (1956) The sea anemones of central California Part III. The acontiarian anemones. Wasmann Journal of Biology, 13, 189-251.

Hand, C. (1961) Two new acontiate New Zealand sea anemones. Transactions of the Royal Society of New Zealand, 1, 75-89.

den Hartog, J. C. (1980) Caribbean shallow water Corallimorpharia. Zoologische Verhandelingen, 1-83.

Hertwig, R. (1882) Die Actinien der Challenger Expedition. Gustav Fischer, Jena, 119.

Hertwig, R. (1888) Report on the Actiniaria dredged by H.M.S. Challenger during the years 1873-1876 [Supplement]. Report on the Scientific Results of the Voyage of the H.M.S. Challenger during the years 1873-76 (Zoology), 26, 156.

Hiles, I. L. (1899) The Gorgonacea collected by Dr. Willey. Zoological Results Based on Material from New Britain, New Guinea, Loyalty Islands and Elsewhere by Arthur Willey, 2, 195-206.

Hutton, F. W. (1879) Contributions to the coelenterate fauna of New Zealand. Transactions and Proceedings of the New Zealand Institute, 12, 274-276.

Ilmoni, (1830) Dr. Ilmoni aus Finnland schickte folgende Beiträge zur Naturgeschichte der Actinien ein. Taf. VII. Isis von Oken, 23, 694-699.

International Commission on Zoological Nomenclature (1985). Opinion 1295: Actinia Linnaeus, 1767 and Actiniidae Rafinesque, 1815 (Coelenterata, Actiniaria) and Pentacta Goldfuss, 1820 (Echinodermata, Holothurioidea): conserved. Bulletin of Zoological Nomenclature, 42, 34-36.

International Commission on Zoological Nomenclature (1987) Official Lists and Indexes of Names and Works in Zoology. International Trust for Zoological Nomenclature, London, 366.

International Commission on Zoological Nomenclature (1999) International Code of Zoological Nomenclature, Fourth Edition. International Trust for Zoological Nomenclature, London, 306.

Johnson, J. Y. (1861) Notes on the sea-anemones of Madeira, with descriptions of new species. Proceedings of the Zoological Society of London, 1861, 298-306.

Johnston, G. (1832) Illustrations in British Zoology. Magazine of Natural History, 5, 163-164.

Johnston, G. (1838) A History of the British Zoophytes. W. H. Lizars, Edinburgh, 341.

Johnston, G. (1847) A History of the British Zoophytes. John Van Voorst, London, 488.

Jourdan, É. (1880) Recherches zoologiques et histologiques sur les Zoanthaires du Golfe de Marseille. Annales des Sciences Naturelles, 10, 1-154.

Keferstein, W. (1862) Untersuchungen über niedere Seethiere. Nachrichten von der G. A. Universität und der Köngl. Gesellschaft der Wissenschaften zu Göttingen, 12, 60-71.

Klunzinger, C. B. (1877) Die Korallthiere des Rothen Meeres. 1: Die Alcyonarien und Malacodermen. Gutmann'schen Buchhandlung, Berlin, 98.

Koch, G. v. (1878) Mittheilungen über Coelenteraten. Zur Phylogenie der Antipatharia. Morphologisches Jahrbuch, 4, $74-86$.

Korotneff, (1886) Polyparium ambulans. Zoologischer Anzeiger, 9, 320-323.

Kwietniewski, C. R. (1896a) Actiniaria von Ternate, nach den Sammlungen von Herrn Prof. Dr. W. Kükenthal. Zoologischer Anzeiger, 19, 388-391.

Kwietniewski, C. R. (1896b) Revision der Actinien, welche von Herrn Prof. Studer auf der Reise der Korvette gazelle um die Erde gesammelt wurden. Jenaische Zeitschrift für Naturwissenschaft, 30, 583-603.

Kwietniewski, C. R. (1897) Ein Beitrag zur Anatomie und Systematik der Actiniarien. Universitaet Jena, Jena, 34. 
Kwietniewski, C. R. (1898) Actiniaria von Ambon und Thursday Island. Zoologische Forschungsreisen in Australien und dem Malayischen Archipelago von Richard Semon, Gustav Fischer, Jena, 385-430.

Lager, E. (1911) Actiniaria. Die Fauna Südwest-Australiens. Ergebnisse der Hamburger südwest-australischen Forschungsreise 1905, Gustav Vischer, Jena, 215-249.

Lesson, R. P. (1830) Description des animaux de la famille des Actiniées. Voyage Autour du Monde, Exécuté par Ordre du Roi, sur la Corvette de La Majesté, La Coquille, pendant les années 1822, 1823, 1824, et 1825, sous le ministère et conformément aux instructions de S. E. M. de Marquis de Clermont-Tonnerre, ministre de la marine, Arthus Bertrand, Paris, 67-83.

Le Sueur, C. A. (1817) Observations on several species of the genus Actinia; illustrated by figures. Journal of the Academy of Sciences of Philadelphia, 1, 149-154, 169-189.

Linnaeus, C. (1758) Systema Natura. Regnum Animale, $10^{\text {th }}$ Edition. Laurentii Salvii, Holmiae.

Linnaeus, C. (1767) Systema Natura. Laurentii Salvii, Holmiae, 1327.

López-González, P. J., den Hartog, J. C., García-Gómez, J. C. (1995) Onubactis rocioi gen. et spec. nov., a new species of Actiniidae (Anthozoa: Actiniaria) from the southern Iberian Peninsula. Zoologische Mededelingen, Leiden, 69, 375-383.

López-González, P. J., Rodríguez, E., Gili, J., Segonzac, M. (2003) New records on sea anemones (Anthozoa: Actiniaria) from hydrothermal vents and cold seeps. Zoologische Verhandelingen, 345, 215-243.

López-González, P. J., Rodríguez, E., Segonzac, M. (2005) A new species of sea anemone (Cnidaria: Anthozoa: Actiniaria) from Manus Basin hydrothermal vents, South-western Pacific. Marine Biology Research, 1, 326-337.

Lütken, C. (1861) Nogle Bémærkninger om de ved de danske Kyster iagttagne Arter af Aktiniernes Gruppe. Videnskabelige Meddelelser fra Dansk Naturhistorisk Forening (Copenhagen), 184-200.

Lütken, C. (1875) A revised catalogue of the Anthozoa and Calycozoa of Greenland. In: Jones, Rupert T. et al., Manual of the Natural History, Geology, and Physics of Greenland and the Neighbouring Regions, Authority of the Lords and Commissioners of the Admirality, London, 186-187.

Manuel, R. L. (1981) British Anthozoa keys and notes for the identification of the species. Academic Press, London, New York, Toronto, Sydney, San Fransisco, 241.

Mathew, K., Kurian, C. V. (1979) A new actinian Paratealia keralensis gen. et sp. nov. from the southwest coast of India. Journal of the Marine Biological Association of India, 18, 159-162.

McMurrich, J. P. (1889a) The Actiniaria of the Bahama Islands, W.I. Journal of Morphology, 3, 1-80.

McMurrich, J. P. (1889b) A contribution to the actinology of the Bermudas. Proceedings of the Academy of Natural Sciences of Philadelphia, 1889, 102-126.

McMurrich, J. P. (1893) Report on the Actiniæ collected by the United States Fish Commission Steamer Albatross during the winter of 1887-1888. Proceedings of the United States National Museum, 16, 119-216.

McMurrich, J. P. (1898) Report on the Actiniaria collected by the Bahama Expedition of the State University of Iowa, 1893. Bulletin from the Laboratories of Natural History, State University of Iowa, 4, 225-249.

McMurrich, J. P. (1901) Report on the Hexactiniæ of the Columbia University Expedition to Puget Sound during the summer of 1896. Annals of the New York Academy of Sciences, 14, 1-52.

McMurrich, J. P. (1904) The Actiniae of the Plate Collection. Zoologische Jahrbücher, 6 Suppl., $215-306$.

Migot, A., Portmann, A. (1926) Sur un actiniaire nouveau de la Méditerranée (Chondranthus denudatum n. g. n. sp.). Comptes Rendus de l'Academie des Sciences, Paris, 182, 87-89.

Milne Edwards, H. (1857) Histoire Naturelle des Coralliaires ou Polypes Proprement Dits, vol. 1. Librairie Encyclopédique de Roret, Paris, 326.

Milne Edwards, H., Haime, J. (1851) Archives du Muséum d'Histoire Naturelle. Gide et J. Baudry, Paris, 502.

Mitchell, P. C. (1890) Thelaceros rhizophora, n. g. et sp., an actinian from Celebes. Quarterly Journal of Microscopical Science, 30, 551-563.

Moseley, H. N. (1877) On new forms of Actiniaria dredged in the deep sea; with a description of certain pelagic surfaceswimming species. Transactions of the Linnean Society (London), 1, 295-305.

Müller, F. (1860) Polypen und Quallen von Santa Catharina. Archiv für Naturgeschichte, 26, 57-63.

Müller, O. F. (1776) Zoologia Danica Prodromus, seu Animalium Daniæe et Norvegia Indigenarum Characteres, Nomina, et Synonyma Imprimis Popularium. Hallageriis, Havniæ, 274.

Neave, S. A. (1939a) Nomenclator Zoologicus vol. I. Zoological Society of London, London, 957.

Neave, S. A. (1939b) Nomenclator Zoologicus vol. II. Zoological Society of London, London, 1025.

Neave, S. A. (1940a) Nomenclator Zoologicus, vol. III. Zoological Society of London, London, 1065.

Neave, S. A. (1940b) Nomenclator Zoologicus, vol. IV. Zoological Society of London, London, 758.

Neave, S. A. (1950) Nomenclator Zoologicus, vol. V. Zoological Society of London, London, 308.

Nordgaard, O. (1905) Hydrographical and Biological Investigations in Norwegian Fiords. John Grieg, Bergen, 254.

Oken, L. (1815) Lehrbuch der Naturgeschichte. Bersasser, Jena, 842.

de Oliveira Pires, D. (1987) Tricnidactis errans, n. gen., n. sp., (Cnidaria, Actiniaria, Haliplanellidae) from Guanabara Bay, Rio de Janeiro, Brazil. Anais da Academia Brasileira de Ciências (Rio de Janeiro), 59, 275. 
de Oliveira Pires (1988) Tricnidactis errans n. gen., n. sp. (Cnidaria, Actiniaria, Haliplanellidae), from Guanabara Bay, Rio de Janeiro, Brazil. Revista Brasileira de Biologia (Rio de Janeiro), 48, 507-516.

Panceri, P. (1868) Nuovo genere di polipi actiniarii. Rendiconto dell' Accademia delle Scienze Fisiche e Matematiche, no vol., 30-32.

Panikkar, N. K. (1936) The structure, bionomics, and systematic position of two new brackish-water Actiniaria from Madras. Proceedings of the Zoological Society of London, no vol., 229-249.

Panikkar, N. K. (1937) The morphology and systematic relationships of a new boloceroidarian from brackish-water near Madras, together with an account of its asexual reproduction. Proceedings of the Indian Academy of Sciences, 5B, 76-90.

Panikkar, N. K. (1938) Studies on Peachia from Madras. Proceedings of the Indian Academy of Sciences, 7B, 182-205.

Parulekar, A. (1969) Neoaiptasia commensali, gen. et. sp. nov.: an actiniarian commensal of hermit crabs. Journal of the Bombay Natural History Society, 66, 57-62.

Pax, F. (1908) Anthozoa. Die Aktinienfauna Westafrikas. Denkschriften der Medizinisch-Naturwissenschaftlichen Gesellschaft, 13, 463-504 [261-302].

Pax, F. (1912) Les actinies de la côte du Pérou. Mission du Service Géographique de l'Armée pour la Mesure d'un Arc de Méridien Equatorial en Amérique du Sud Sous le Contrôle Scientifique de l'Académie des Sciences, Gauthier-Villars, Imprimeur-Libraire, Paris, 1-28.

Pax, F. (1922) Diagnosen neuer Actiniarien aus der Ausbeute der Deutschen (1901-1903) und der Französischen (19081910) Südpolar-Expedition. Zoologischer Anzeiger, 54, 74-92.

Pax, F. (1924) Anthozoen des Leidener Museums. Zoologische Mededelingen, Leiden, 8, 1-17.

Pennant, T. (1777) A British Zoology. Benj. White, London, 136.

Pfeffer, G. (1889) Zur Fauna von Süd-Georgien. Jahrbuch der Hamburgischen Wissenschaftlichen Anstalten, 6, $39-55$.

de Quatrefages, A. (1842) Mémoire sur les edwardsies (Edwardsia, nob.) nouveau genre de la famille des actinies. Annales des Sciences Naturelles, 18, 65-109.

Quoy, J. R., Gaimard, P. (1833) Voyage de Découvertes de l'Astrolabe Exécuté par Ordre du Roi, Pendant les Années 1826-1827-1828-1829, sous le Commandement de M. J. Dumont D'Urville. J. Tastu, Paris, 390.

Rathke, H. (1843) Beiträge zur fauna Norwegens. Nova Acta Academiae Caesareae Leopoldino-Coralinae Naturae Curiosorum, 20, 137-149.

Riemann-Zürneck, K. (1978) Actiniaria des Südwestatlantik IV. Actinostola crassicornis (Hertwig, 1882) mit einer Diskussion verwandter Arten. Veröffentlichungen des Institutes für Meeresforschung Bremerhaven, 17, 65-85.

Riemann-Zürneck, K. (1979) Two disc-shaped deep sea Anthozoa from the Gulf of Biscay, with a survey of adaptation types in the Actiniaria. Zoomorphologie, 93, 227-243.

Riemann-Zürneck, K. (1986) On some abyssal sea anemones of the North Atlantic (Actiniaria: Hormathiidae). Mitteilungen aus dem Hamburgischen Zoologischen Museum und Institut, 83, 7-29.

Riemann-Zürneck, K. (1997) A hemisessile anemone from the Porcupine Abyssal Plain, North Atlantic Ocean: Iosactis vagabunda gen. nov., sp. nov. Journal of the Marine Biological Association of the United Kingdom, 77, 1011-1025.

Riemann-Zürneck, K., Gallardo, V. A. (1990) A new species of sea anemone (Saccactis coliumensis n. sp.) living under hypoxic conditions on the central Chilean shelf. Helgoländer Meeresuntersuchungen, 44, 445-457.

Riemann-Zürneck, K., Griffiths, C. L. (1999) Korsaranthus natalensis (Carlgren, 1938) nov. comb. (Cnidaria: Actiniaria) a mobile sea anemone attacking octocorals. South African Journal of Zoology, 34, 190-196.

Risso, A. (1826) Histoire Naturelle des Principales de l'Europe Méridionale. F.-G. Levrault, Strasbourg, 402.

Rodríguez, E., López-González, P. J. (2003) Stephanthus antarcticus, a new genus and species of sea anemone (Actiniaria, Haloclavidae) from the South Shetland Islands, Antarctica. Helgoländer Marine Research, 57, 54-62.

Roule, L. (1909) Hexactinides. Expedition Antarctique Française (1903-1905), 1-19.

Rüppell, E., Leuckart, F. S. (1828) Atlas zu der Reise im Nördlichen Afrika von Eduard Rüppell, Neue Wirbellose Thiere des Rothen Meers. Heinr. Ludw. Brunner, Frankfurt am Main, 47.

Sanamyan, N. P. (2001) New and poorly known Actiniaria from the NW Pacific. Zoosystematica Rossica, 9, 1-10.

Sanamyan, N. P., Sanamyan, K. E. (1998) Some Actiniaria from the Commander Islands (Cnidaria: Anthozoa). Zoosystematica Rossica, 7, 1-8.

Sanamyan, N. P., Sanamyan, K. E. (2007) Deep-water Actiniaria from East Pacific hydrothermal vents and cold seeps. Invertebrate Zoology, 4, 83-102.

Sars, M. (1829) Bidrag til Söedyrenes Naturehistorie. Christian Dahl, Bergen, 59.

Sars, M. (1835) Polypernes, Acalephernes, Radiaternes, Annelidernes og Molluskernes Classer. Thorstein Hallagers Forlag, Bergen, 81.

Sars, M. (1851) Beretning om en i Sommeren 1849 foretagen zoologisk Reise i Lofoten og Finmarken. Nyt Magazin for Naturvidenskaberne, 6, 121-211.

Saville-Kent, W. (1893) The Great Barrier Reef of Australia; Its Products and Potentialities. W. H. Allen \& Co., London, 387.

Schmarda, L. K. (1852) Zur naturgeschichte der Adria. Denkschriften der Kaiserlichen Akademie der Wissenschaften 
(Wien), 4, 117-137.

Schmidt, H. (1972) Prodromus zu einer Monographie der mediterranean Aktinien. Zoologica, 42, 1-121.

Schmidt, H. (1979) Beiträge zur Differentialdiagnose, Morphologie und Evolution der Edwardsiidae (Actiniaria, Anthozoa) I. Die Gattung Alfredus nov. gen. mit der Typusart A. lucifugus (Fischer, 1888). Sonderdrucke aus der Zeitschrift für Zoologische Systematik und Evolutionsforschung, 17, 211-220.

Simon, J. A. (1892) Ein Beitrag zur Anatomie und Systematik der Hexactinien. Druck von Val. Hvfling, Kapellenstrasse 3, München, 5-106.

Sluiter, C. P. (1888) Über zwei merkwürdige Gephyreen aus der Bai von Batavia. Natuurkundig Tijdschrift voor Nederlandsch Indië, 48, 233-248.

Stechow, E. (1921) Neue Genera und Species von Hydrozoen und anderen Evertebraten. Archiv für Naturgeschichte, 87, 248-265.

Stephenson, T. A. (1918a) Coelenterata. Part I. -Actiniaria. Natural History Reports on British Antarctic ("Terra Nova”) Expedition 1910, 5, 1-68.

Stephenson, T. A. (1918b) On certain Actiniaria collected off Ireland by the Irish Fisheries Department, during the years of 1899-1913. Proceedings of the Royal Irish Academy, 34B, 106-164.

Stephenson, T. A. (1920) On the classification of Actiniaria. Part I.-Forms with acontia and forms with a mesogloeal sphincter. Quarterly Journal of Microscopical Science, 64, 425-574.

Stephenson, T. A. (1921) On the classification of Actiniaria. Part II.-Consideration of the whole group and its relationships, with special reference to forms not treated in Part I. Quarterly Journal of Microscopical Science, 65, 493-576.

Stephenson, T. A. (1922) On the classification of Actiniaria. Part III. - Definitions connected with the forms dealt with in Part II. Quarterly Journal of Microscopical Science, 66, 247-319.

Stephenson, T. A. (1925) On a new British sea anemone. Journal of the Marine Biological Association of the United Kingdom, 13, 880-890.

Stephenson, T. A. (1929) A contribution to actinian morphology: the genera Phellia and Sagartia. Transactions of the Royal Society of Edinburgh, 56, 121-139.

Stephenson, T. A. (1935) The British Sea Anemones. Volume II. The Ray Society, London, 426.

Stimpson, W. (1856a) Descriptions of some of the new marine invertebrata from the Chinese and Japanese Seas. Proceedings of the Academy of Natural Sciences of Philadelphia, 7, 375-384.

Stimpson, W. (1856b) On some remarkable marine invertebrata inhabiting the shores of South Carolina. Proceedings of the Boston Society of Natural History, 5, 110-118.

Stoliczka, F. (1869) On the anatomy of Sagartia schilleriana and Membranipora bengalensis, a new coral and a bryozoon living in brackish water at Port Canning. Journal of the Asiatic Society of Bengal, 38, $28-63$.

Stuckey, F. G. (1909) A review of the New Zealand Actiniaria known to science, together with a description of twelve new species. Transactions of the New Zealand Institute, 41, 374-398.

Studer, T. (1879) Zweite Abtheilung der Anthozoa polyactinia, welche während der Reise S. M. S. Corvette Gazelle um die Erde gesammelt wurden. Monatsberichte der Akademie der Wissenschaften, Berlin, 25, 524-550.

Thompson, W. (1853) Description of a new species of Corynactis. Proceedings of the Zoological Society of London, 21, 107-108.

Thompson, W. (1858) Remarks on the British Actiniadae, and re-arrangement of the genera. Proceedings of the Zoological Society of London, 26, 145-149.

Tilesius, G. T. (1809) De nova Actiniarum specie gigantea, Kamtschatica. Memoires de l'Académie Impériale des Sciences de St. Pétersbourg, 1, 388-422.

Torrey, H. B. (1902) Papers from the Harriman Alaska Expedition. XXX. Anemones, with discussion of variation in Metridium. Proceedings of the Washington Academy of Sciences, 4, 373-410.

Uchida, T. (1932a) Description of a new actinian, Andwakia Hozawai n. sp. Proceedings of the Imperial Academy (Japan), 8, 394-396.

Uchida, T. (1932b) On a new actinian, Milne-Edwardsia akkeshi n. sp., from northern Japan. Annotationes Zoologicae Japonenses, 13, 571-575.

Uchida, T. (1938) Actiniaria of Mutsu Bay. Report of the Biological Survey of Mutsu Bay, 13, 281-317.

Uchida, T. (1960) Carcinactis ichikawai, n. gen.; n. sp., an actiniarian commensal with the crab Dorippe granulata. Japanese Journal of Zoology, 12, 595-601.

Verrill, A. E. (1864a) List of the polyps and corals sent by the Museum of Comparative Zoölogy to other institutions in exchange, with annotations. Bulletin of the Museum of Comparative Zoology (Harvard University), 1, $29-60$.

Verrill, A. E. (1864b) Revision of the Polypi of the eastern coast of the United States. Memoirs of the Boston Society of Natural History, 1, 1-45.

Verrill, A. E. (1865) Classification of polyps (Extract condensed from a Synopsis of the Polypi of the North Pacific Exploring Expedition, under Captains Ringgold and Rodgers, U.S.N.). Proceedings of the Essex Institute, 4, 145152.

Verrill, A.E. (1868) Synopsis of the polyps and corals of the North Pacific Exploring Expedition, under Commodore C. 
Ringgold and Capt. John Rodgers, U.S.N., from 1853 to 1856. Collected by Dr. Wm. Stimpson, Naturalist to the Expedition. Part IV. Actiniaria [First part]. Communications of the Essex Institute, 5, 315-330 [reprint 1-16].

Verrill, A.E. (1869a) Review of the corals and polyps of the west coast of America. Transactions of the Connecticut Academy of Arts and Sciences, 1, 377-558.

Verrill, A.E. (1869b) Synopsis of the polyps and corals of the North Pacific Exploring Expedition, under Commodore C. Ringgold and Capt. John Rodgers, U.S.N., from 1853 to 1856. Collected by Dr. Wm. Stimpson, naturalist to the Expedition. Part IV. Actiniaria. [Second part]. Proceedings of the Essex Institute, 6, 51-104 [reprint 17-69].

Verrill, A.E. (1879) Notice of recent additions to the marine fauna of the eastern coast of North America, No. 5. American Journal of Science and Arts, 17, 472-474.

Verrill, A.E. (1880) Notice of recent additions to the marine invertebrata, of the northeastern coast of America, with descriptions of new genera and species, and critical remarks on others. Part I — Annelida, Gephyræa, Nemertina, Nematoda, Polyzoa, Tunicata, Mollusca, Anth. Proceedings of the United States National Museum, 2, 165-205.

Verrill, A.E. (1882) Notice of the remarkable marine fauna occupying the outer banks off the southern coast of New England, No. 4. American Journal of Science and Arts, 23, 216-225.

Verrill, A.E. (1883) Reports on the Anthozoa, and on some additional species dredged by the "Blake" in 1877-1879, and by the U. S. Fish Commission Steamer "Fish Hawk" in 1880-82. Bulletin of the Museum of Comparative Zoology (Harvard University), 11, 1-72.

Verrill, A.E. (1898) Descriptions of new American actinians, with critical notes on other species, I. American Journal of Science and Arts, 6, 493-498.

Verrill, A.E. (1899a) Descriptions of imperfectly known and new Actinians, with critical notes on other species, II. American Journal of Science and Arts, 7, 41-50.

Verrill, A.E. (1899b) Descriptions of imperfectly known and new Actinians, with critical notes on other species, III. American Journal of Science and Arts, 7, 143-146.

Verrill, A.E. (1899c) Descriptions of imperfectly known and new Actinians, with critical notes on other species, IV. American Journal of Science and Arts, 7, 205-218.

Verrill, A.E. (1899d) Descriptions of imperfectly known and new Actinians, with critical notes on other species, V. American Journal of Science and Arts, 7, 375-380.

Verrill, A.E. (1922) The Actiniaria of the Canadian Arctic Expeditions, with notes on interesting species from Hudson Bay and other Canadian localities. Report on the Canadian Arctic Expedition 1913-1918, 8, 89-164.

Verrill, A.E. (1928) Hawaiian shallow water Anthozoa. Bernice P. Bishop Museum Bulletin, 49, 3-30.

Wassilieff, A. (1908) Japanische Actinien. Abhandlungen des Mathematischen-Physikalischen Institutes der Kaiserlichen Bayerischen Akademie der Wissenschaften, Suppl. 1, 1-49.

Watzl, O. (1922) Die Actiniarien der Bahamainseln. Arkiv für Zoologi, 14, 1-89.

Williams, R.B. (1981) A sea anemone, Edwardsia meridionalis sp. nov., from Antarctica and a preliminary revision of the genus Edwardsia de Quatrefages, 1841 (Coelenterata: Actiniaria). Records of the Australian Museum, 33, 325360 .

Wilson, J.B. (1890) On a new actinia, Hoplophoria coralligens. Studies at the Biological Laboratory of the Johns Hopkins University (Baltimore), 4, 379-387.

Wright, T.S. (1856) On two new actinias from Arran. Proceedings of the Royal Physical Society of Edinburgh, 1, 70-72.

Wright, T.S. (1859) Notes on the Irish Actinidæ, etc., with especial reference to their distribution. Proceedings of the Dublin University Zoological and Botanical Association, 1, 174-188.

Wyragévitch, T. (1905) Sur la Halcampella ostroumowi, mihi n. sp., trouvée dans la mer Noire. Travaux du Laboratoire Zoologique et de la Station Biologique de Sébastopol, 1-14.

Zamponi, M.O. (1974) Neoparacondylactis haraldoi gen. et sp. nov. (Actiniaria, Actiniidae). Physis (Buenos Aires), 33A, 543-547.

Zamponi, M.O. (1976) Enmienda a la familia Sideractiidae Danielssen 1890 (Anthozoa: Corallimorpharia) con la creacion de Sphincteractis sanmatiensis gen. et sp. nov. Physis (Buenos Aires), 35A, 127-133.

Zamponi, M.O. (1978a) La anemonofauna de Mar del Plata y localidades vecinas II. La anemonas Mesomyaria. (Coelentherata: Actiniaria). Neotropica, 24, 21-26.

Zamponi, M.O. (1978b) Sobre la anemona Paraisometridium pehuensis, gen. y sp. nov. (Actiniaria: Metridiidae). Neotropica, 24, 117-122.

Zamponi, M.O. (1980) La anemonofauna de Mar del Plata y localidades vecinas III. Las anemonas Acontiaria (Coelenterata Actiniaria). Neotropica, 25, 145-154. 